NOT FOR QUOTATION

WITHOUT PERMISSION

OF THE AUTHOR

\title{
PUBLIC DATABASE SERVICES IN HUNGARY
}

I. Sebestyen

November 1982

WP-82-111

Working Papers are interim reports on work of the International Institute for Applied Systems Analysis and have received only limited review. Views or opinions expressed herein do not necessarily represent those of the Institute or of its National Member Organizations.

INTERNATIONAL INSTITUTE FOR APPLIED SYSTEMS ANALYSIS 2361 Laxenburg, Austria 


\section{PREFACE}

This working paper is part of the IIASA study "Telecommunication Equipment and Administrative Procedures relevant to Experimental and Operational East-West Computer Connections". This work is supported both by the Control Data Corporation in Minneapolis and the Austrian Ministry for Science and Research in Vieanna. 


\section{CONTENTS}

1. INTRODUCTION 1

(I) Classification of Databases 2

(II) The Database Producers 3

(III) The Database Services 4

2. PUBLIC DATABASE SERVICES IN HUNGARY 6

2.1. State of the Hungarian Database Service Industry B

2.2. General Growth Figures of the Hungarian Database 17 Industry

2.3. Cost of Database Usage 22

2.4. Origin of Databases Serviced Publicly in Hungary 26

2.5. Computer Hardware and Systems Software Used 29

2.6. Information Retrieval Software Used 43

2.7. Telecommunication Needs of Database Services 46

2.B. Online Access to Databases Abroad 49 from Hung ary

3. CONCLUSIONS

52

REFERENCES 


\section{PUBUIC DATABASE SERVICES IN HUNGARY}

1. Sebestyen

\section{INTRODUCTION}

One of the most important categories of data flow applications is databases--especially public databases. Without going into depth concerning the philosophy of database classification, which is discussed in length, for example, in $[1,2]$, in what follows we are going to describe and analyze the state of public database production and services in Hungary. All data and statistics that are used were published by the Hungarian Central Statistical Office (Országas Statisztikai Hivatal) [3], the National Technical Library and Documentation Center (Országos Mueszaki Koenyvtár es Dokumentácios Koezpont - OMKDK) and by the Information Center for Construction and Building (Epitésuegyi Tájékoztatási Koezpont) [4] and in other printed publications. At this early point we would like to mention that OMKDK was recently reorganized and extended 
by new functions and now is called OMIK, but throughout the paper when mentioning this institution we refer to its old name, which was valid when the data for this study were collected.

In order to ensure that the terminology used in this paper will be unanimously understood, let us recall some of the known terminology used in connection with the database service industry:

\section{(I) Classification of Databases}

Databases in general contain numeric, textual, or a combination of numeric and textual, information in a wide range of subject areas that can be used to meet both general and specific information needs. According to [2], databases differ in a number of ways: in subject, scope, geographic and chronological coverage, periodicity of release of new information by the producer, and frequency of updating (the addition of newly released information to the database). In addition, they differ in the type of information or data that they contain. A classification scheme often used in the literature [2] is:

Reference Databases. Refers or "points" users to another source (e.g., a document, an organization, or an individual) for additional details or for the complete text.

Bibliographic. Contains citations and, sometimes, abstracts of the printed literature, e.g., journal articles, reports, patents, dissertations, conference proceedings, books, or newspaper items. 
Referral. Contains references and, sometimes, abstracts or summaries of non-published information. Generally this will refer users to organizations, individuals, audiovisual materials and other non-print media, for further information.

Source Databases. Those that contain complete data or the full text of the original source information.

Numeric. Contains original survey data and/or statistically manipulated representations of data. These are generally in the form of a time series, which represent measurements (e.g., tons or dollars) over time for a given variable (e.g., production or shipment statistics for a given product or industry).

Textual-Numeric. These are generally databases of records that contain a number of data elements, or fields with a combination of textual information and numeric data.

Properties. Contains dictionary or handbook-type data, typically, chemical and physical properties.

Full Text. Contains records of the complete text of an item, e.g., a newspaper item, a specification, or a court decision.

\section{(II) The Database Producers}

Databases are developed by a group of suppliers referred to as "producers". In some cases, particularly for reference databases, producers are primarily publishers of printed index and abstract journals. These organizations--in both the public and private sectors--acquire, screen, select, index, and sometimes abstract or summarize the primary litera- 
ture. To produce their printed publications, these organizations have adopted automated systems for phototypesetting and thereby generate a magnetic tape that can be used further for computerized processing, particularly in storage and retrieval systems.

Source databases, on the other hand, are produced by a number of different types of organizations. Some producers of these databases are also publishers of reports and other publications. Others have, as their main line of business, research, consulting, and advisory services in the areas covered by the database they produce. Still others are government agencies that, like their counterparts in agencies that produce bibliographic databases, have a responsibility for the dissemination of information collected or generated in their particular areas. Some producers process and package data into databases that were originally collected by some other source, often the federal government. In their packaging, these producers frequently bring together data from a number of different sources and sometimes increase the value of a collection by including additional data $\mathrm{a}_{1}$ such as forecasts, that they generate.

\section{(III) The Database Services}

Computer-based database services are provided by computer service organizations (often by the database producers themselves) equipped with appropriate computer hardware and software to mount the databases to be serviced on their computer and to retrieve the required information. In the process of retrieval there are basically two different categories--which we also use in some of the following tables. 
(1) selective dissemination of information (for short SDI) where information is periodically filtered according to a certain category foften called profile) from the new increments of the database.

(2) During the so-called retrospective search of information where a browse on the full (cumulated) database is to be performed in order to find the requested information (profile) over a long period.

Other classifications of services we distinguish between are the socalled offline and online services:

(1) Both SDI and retrospective searches can be made in an offline regime, in this manner the request for information is processed in batch mode, i.e. not instantaneously after the request has been made. Offline regime, although generally wrongly regarded as "old fashioned", is still most useful in our opinion--especially for periodical SDI service subscriptions.

(2) Online regime is an elegant, rather new way of retrieving information from a database instantaneously. For this purpose usually a powerful timesharing computer equipped with an appropriate disc and terminal configuration is used. By this technique both SDI and retrospective searches can be performed; however, the interactive mode of this service is most suitable for finding on a trial and see basis the right search strategies and obtaining the desired result instantaneously. Thus, this type of regime is preferably used for retrospective searches and in factual databases. Online services are typical computer network applications. Time sharing data centers in this regime are linked as hosts to the computer network, users get access to these systems through the network by using 
terminals. Larger public computer networks such as TYMNET or EURONET not only provide services for one single country, but allow the use of online services over many borders. Similar is the case for the increasing number of interlinked national PTT computer networks. By this fact online access to databases in foreign locations have become one of the most discussed information policy issues--under the umbrella of transborder data flow policies.

In this paper we discuss and analyze the present state of the Hungarian database industry and public database services, and predict future trends of this industry in Hungary. In the analysis special emphasis was placed on the history of the database industry in the country; the computer hardware and software systems used, the stage of the telecommunication service infrastructure, information policy issues, and potentials for international cooperation in this field. We will show that in Hungary-as in other countries-- this industry has reached extremely high growth figures, and will be an important participant in transborder data flows.

\section{PUBLIC DATABASE SERVICES IN HUNGARY}

The database industry, as with the computer industry--is relatively young. In 1954 the number of machine readable data files publicly available did not exceed more than some ten worldwide, and databases came into being only as some kind of "sideproduct" of referral journals and different kinds of bibliographies. By about the end of the sixties machine readable data files were found in almost all important disciplines of applied sciences and technologies. The introduction of online database and services at the end of the sixties and in the early seventies, were 
connected to the hardware and system software development of computer systems and telecommunication data networks. By the early seventies major manufacturers introduced time sharing mainframes to the market, and data networks through dial-up and leased telephone lines gradually became available to users. It was also about that time that new types of databases mainly linked to these services started to emerge namely, numeric databases.

The development of the database services and the database industry in Hungary generally followed the above trend, obviously influenced by some country--specific circumstances and factors, such as special requirements for information by the Hungarian industry and research, long traditions in the library and documentation services, the state of computer and telecommunication infrastructure and the general economic situation of the country.

In the following discussion of the Hungarian database industry we will provide a thorough "cross-section" of it based on official statistical data taken between late 1979 and early 1981. Taking these statistics as a basis, we will first look backwards to trace the development of the Hungarian database industry and then discuss its present situation in order to help predict its future path. As to the statistics, the latest data on the computer service industry originate from the end of 1979 and first half of 1980; the latest data on the database industry are dated end of 1980 and . the first quarter of 1981 . In such a rapidly evolving field as computer service-- and database-industry, a time difference of one year can bring significant changes and we have tried to take this into consideration when making the analysis. Furthermore, although all data are the latest 
available, the known fast development of the above fields (databases, computers, telecommunication infrastructure) have since brought about further significant changes, which could obviously not yet be reflected in the statistics. We have tried however to give consideration to this in a descriptive way.

As a last remark, before diving into the analysis of figures and tables, it should be mentioned that a large amount of statistical data offers the temptation of "shovelling" around numbers and figures in order to bring out just the type of results, proofs and lessons that the authors believe correct. We have tried not to fall into the above trap and have made all the present analysis as objective as possible. Nevertheless we recommend the present data not be used a as reference source, but only to be regarded as a tool for better orientation.

\subsection{State of The Hungarian Database Service Industry}

Table 1 represents a list of all public database services available in Hungary in the first quarter of 1981.

The term "publicly available" means that in principle--if fulfilling certain well defined conditions--all institutions in Hungary can become users of these services. These conditions differ from case to case; some databases can be used without any restriction and one is even free of charge, but for the majority of databases the completion of a standard agreement form is an adequate precondition of access. Finally, there are databases, such as the DERWENT ones, where, according to the agreement between DERWENT and the Hungarian service suppliers, "heavy and expensive" preconditions are to be fulfilled in order to become a user of these data- 
base services. But overall, as everywhere in the world these databases are classified as public database services, as opposed for example to those databases that serve only the internal needs of companies.

Table 1 shows that at the beginning of 1981, 25 databases were serviced in Hungary, and Table $Z$ indicates that there are 13 more that are under preparation for introduction by 1983. The first public database service was established as early as 1970 , but the majority of databases were installed during the last three years. The subject category of the databases suggest that there is a strong interest in disciplines such as chemistry, pharmacology, agriculture and in scientific technical information in general. Since the above "statistical snapshot" was taken in early 1981, and especially with the growing use of remote foreign online services (which unfortunately with regards to our statistics were just about to start when the data were collected and therefore only access to the INIS databases in Vienna could be reflected in it) there is a growing interest for numeric databases, and especially for economical and patent information. Also the early interest of the pharmaceutical and chemical industries in databases are not surprising at all. First of all Hungary has long traditions and relative weight in Europe in those industries and these users have already learned how really important it is to be well informed if they want to keep pace with foreign competition. For this purpose their interest for information and documentation goes well back to before the existence of databases and it was relatively easy for their information centers to embrace these new tools of information retrieval in their standard practice. As can be seen from Table 1 most pharmaceutical- and chemistry- related information is processed in Hungary itself yet in an 
Table 1. Public database services in Hungary (1980). (Source [4] Duzs. J. et al 1981.)

\begin{tabular}{|c|c|c|c|c|c|}
\hline No. & $\begin{array}{l}\text { Name of } \\
\text { database }\end{array}$ & Coverage & $\begin{array}{l}\text { Number of } \\
\text { records } \\
(1980)\end{array}$ & $\begin{array}{l}\text { Number of } \\
\text { new records } \\
\text { in } 1980 \\
(000 \mathrm{~s})\end{array}$ & $\begin{array}{l}\text { Database } \\
\text { producer }\end{array}$ \\
\hline 1. & AGDOC & Agricultural chemistry & $: 00$ & 5 & $\begin{array}{l}\text { Derwent Publ } \\
\text { Limited } \\
\text { (UK) }\end{array}$ \\
\hline 2. & AGRIS & $\begin{array}{l}\text { Agriculture, plant growing, } \\
\text { forestry, nutrition science. } \\
\text { fshery, environmental } \\
\text { control, etc. }\end{array}$ & $\begin{array}{l}600 \\
(\mathrm{UN})\end{array}$ & 130 & FAO \\
\hline 3. & AOBIPD & Kultidisciplinary patents & 4.500 & 900 & $\begin{array}{l}\text { COMECON } \\
\text { (USSR) }\end{array}$ \\
\hline 4. & BIBDOSZ & $\begin{array}{l}\text { Manage ment science. } \\
\text { management training }\end{array}$ & 23 & 2 & $\begin{array}{l}\text { Orszb́gos } \\
\text { Vezetbképzb́ } \\
\text { Központ }\end{array}$ \\
\hline 5. & CA SEARCH & Chemistry & 3,500 & 360 & $\begin{array}{l}\text { Chemical Abstract } \\
\text { Service } \\
\text { (USA) }\end{array}$ \\
\hline 6. & $\begin{array}{l}\text { CCDB } \\
\text { (Cambridge } \\
\text { Crystallographic } \\
\text { Data Base) } \\
\end{array}$ & $\begin{array}{l}\text { Crystal structure and } \\
\text { molecule geometry of } \\
\text { organic \& metalorg anic } \\
\text { compounds }\end{array}$ & 28 & 2 & $\begin{array}{l}\text { Crystrallographic } \\
\text { Data Centre. } \\
\text { Univ Chem. Lab } \\
\text { (UK) } \\
\end{array}$ \\
\hline 7. & $\mathrm{CIN}$ & $\begin{array}{l}\text { Marketing in the } \\
\text { Cbemical industry }\end{array}$ & 340 & 50 & $\begin{array}{l}\text { Cbemical Abstract } \\
\text { Service } \\
\text { (USA) }\end{array}$ \\
\hline 8. & ${ }^{13} \mathrm{C}-\mathrm{NMR}$ & $\begin{array}{l}13_{C-M N R} \text { spectascopy } \\
\text { data }\end{array}$ & 16 & 35 & $\begin{array}{l}\text { YTA KKJ } \\
\text { (Hungary) }\end{array}$ \\
\hline 9. & COMPENDEX & $\begin{array}{l}\text { Multidisciplinary. } \\
\text { technology, science }\end{array}$ & 970 & 100 & $\begin{array}{l}\text { Engine ering Index, lac. } \\
\text { (USA) }\end{array}$ \\
\hline 10. & CRDS & $\begin{array}{l}\text { organic chemical } \\
\text { reactions \& processes }\end{array}$ & 38 & 3 & $\begin{array}{l}\text { Derwent Public. } \\
\text { Limited. } \\
\text { (UK) }\end{array}$ \\
\hline 11. & FARMDOC & Pharmatology & 140 & 10 & $\begin{array}{l}\text { Derweat Public. } \\
\text { Limited } \\
\text { (UK) }\end{array}$ \\
\hline$\overline{12 .}$ & INIS & $\begin{array}{l}\text { Use of atomic energy, } \\
\text { atomic energy power station } \\
\text { izotopes, nuclear biology, } \\
\text { chemistry, nuclear control } \\
\text { lectnology, nuclear medicine. } \\
\text { radiation protection etc. }\end{array}$ & 572 & 80 & $\begin{array}{l}\text { International } \\
\text { Atomic Energy } \\
\text { Agency } \\
\text { (UN) }\end{array}$ \\
\hline$\overline{23}$ & INSPEC & $\begin{array}{l}\text { Physics. electronics, } \\
\text { communications technology, } \\
\text { automation, control technology, } \\
\text { system scieace, informatique, } \\
\text { computer technology }\end{array}$ & 1,500 & $?$ & $\begin{array}{l}\text { Institution of } \\
\text { Electrical } \\
\text { Engineers } \\
\text { (UK) }\end{array}$ \\
\hline$\overline{14}$ & IRB & $\begin{array}{l}\text { Architecture, } \\
\text { construction industry }\end{array}$ & 20 & 6 & $\begin{array}{l}\text { Frauephofer } \\
\text {-Gesellschaft }\end{array}$ \\
\hline 15. & METADEX & $\begin{array}{l}\text { Iron, metal, industry } \\
\text { and science }\end{array}$ & 450 & 38 & $\begin{array}{l}\text { Americal Soc } \\
\text { for Vetals } \\
\text { (USA) }\end{array}$ \\
\hline 16. & $M D$ & $\begin{array}{l}\text { Computer technology and } \\
\text { scieace; reports. } \\
\text { software, standards, etc. }\end{array}$ & 32 & 6 & $\begin{array}{l}\text { SEK } \\
\text { (Hungary) }\end{array}$ \\
\hline$\overline{17}$ & NAIVR & $\begin{array}{l}\text { Agrochemistry, } \\
\text { plant protection }\end{array}$ & 4 & 4 & $\begin{array}{l}\text { VEX-NAK } \\
\text { (Hungary) }\end{array}$ \\
\hline$\overline{18}$ & PASCAL-GEODE & Geo-sciences & 280 & 40 & $\begin{array}{l}\text { CNRS } \\
\text { (France) }\end{array}$ \\
\hline$\overline{19}$ & PESTDOC & $\begin{array}{l}\text { Insecticides, } \\
\text { plant protection }\end{array}$ & 90 & $B$ & $\begin{array}{l}\text { Derweat Public } \\
\text { Limited } \\
\text { (UK) }\end{array}$ \\
\hline 20. & RINGDOC & $\begin{array}{l}\text { Phamatology: chemistry } \\
\text { and medicalbiology }\end{array}$ & 600 & 53 & $\begin{array}{l}\text { Derwent Public } \\
\text { Limited }\end{array}$ \\
\hline$\overline{21 .}$ & $\mathrm{SCI}$ & $\begin{array}{l}\text { Multidisciplinary science } \\
\text { index }\end{array}$ & 6.600 & 518 & $\begin{array}{l}\text { Institute for } \\
\text { Scientific lnformation } \\
\text { (USA) }\end{array}$ \\
\hline$\overline{22 .}$ & STATINFORM & $\begin{array}{l}\text { Sociology, demography. } \\
\text { statistics, economy. etc. }\end{array}$ & 20 & 9 & $\begin{array}{l}\text { KSH Kônyvtár és } \\
\text { Dokumentácios Szolg ́́lat } \\
\text { (Hungary) }\end{array}$ \\
\hline$\overline{23}$ & SZAMOK-ISIS & $\begin{array}{l}\text { Informatiques, computer } \\
\text { technology and computer } \\
\text { science }\end{array}$ & 46 & 7 & $\begin{array}{l}\text { Nemzetkózi Stámltás- } \\
\text { tecbrikai Oktató és } \\
\text { Tójékoztató Központ } \\
\text { (Hungary) }\end{array}$ \\
\hline$\overline{24}$ & VETDOC & Veterarian medicine & 54 & 4 & $\begin{array}{l}\text { Derwent Public. } \\
\text { Limited } \\
\text { (UK) }\end{array}$ \\
\hline 25 . & $\begin{array}{l}\text { INFORMATION ON } \\
\text { WORLD POLITICS }\end{array}$ & $\begin{array}{l}\text { International politics, } \\
\text { economies (news) }\end{array}$ & 18 & 3 & $\begin{array}{l}\text { Országgyülési Könyutár } \\
\text { (Hungary) }\end{array}$ \\
\hline
\end{tabular}




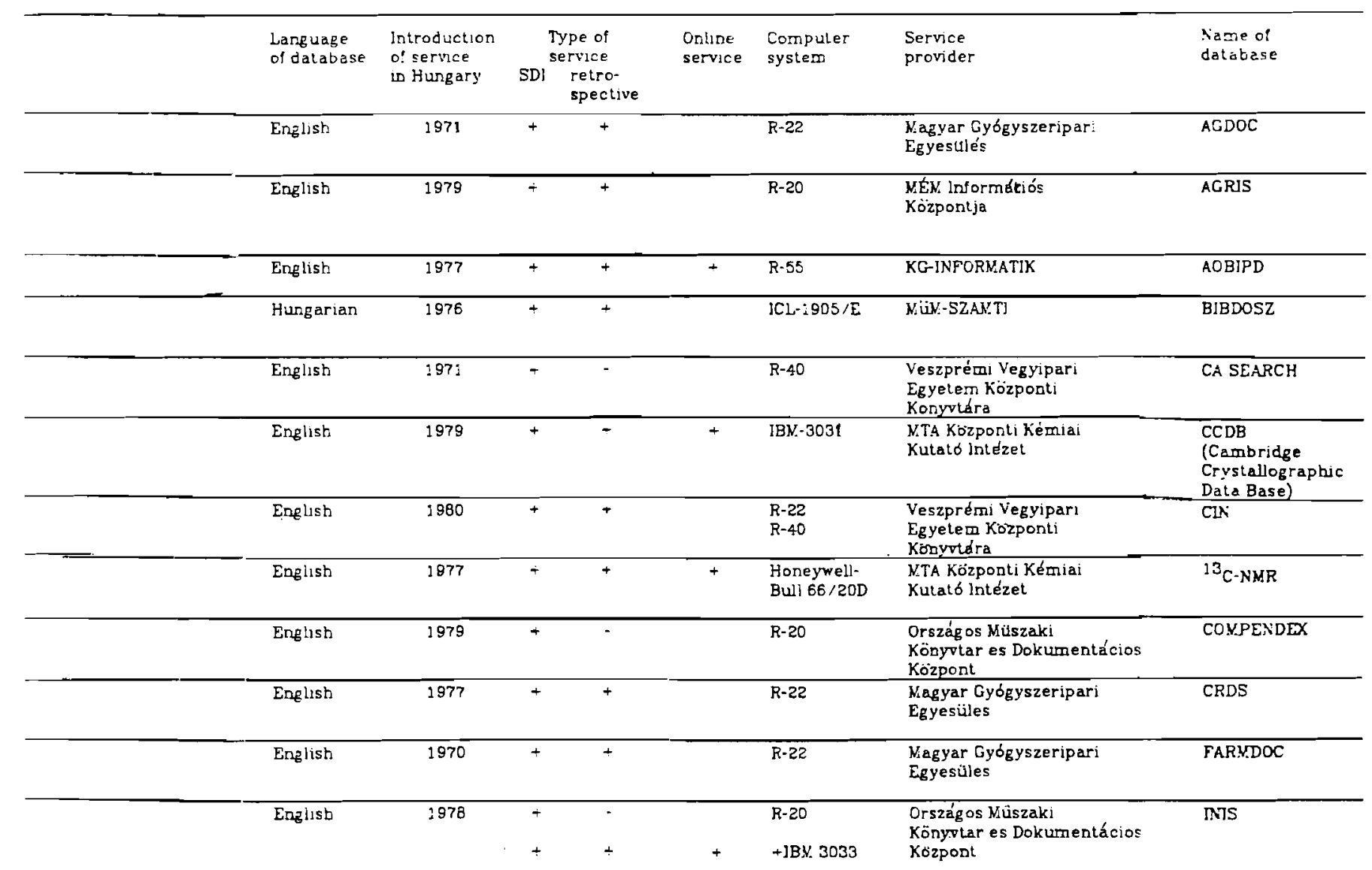

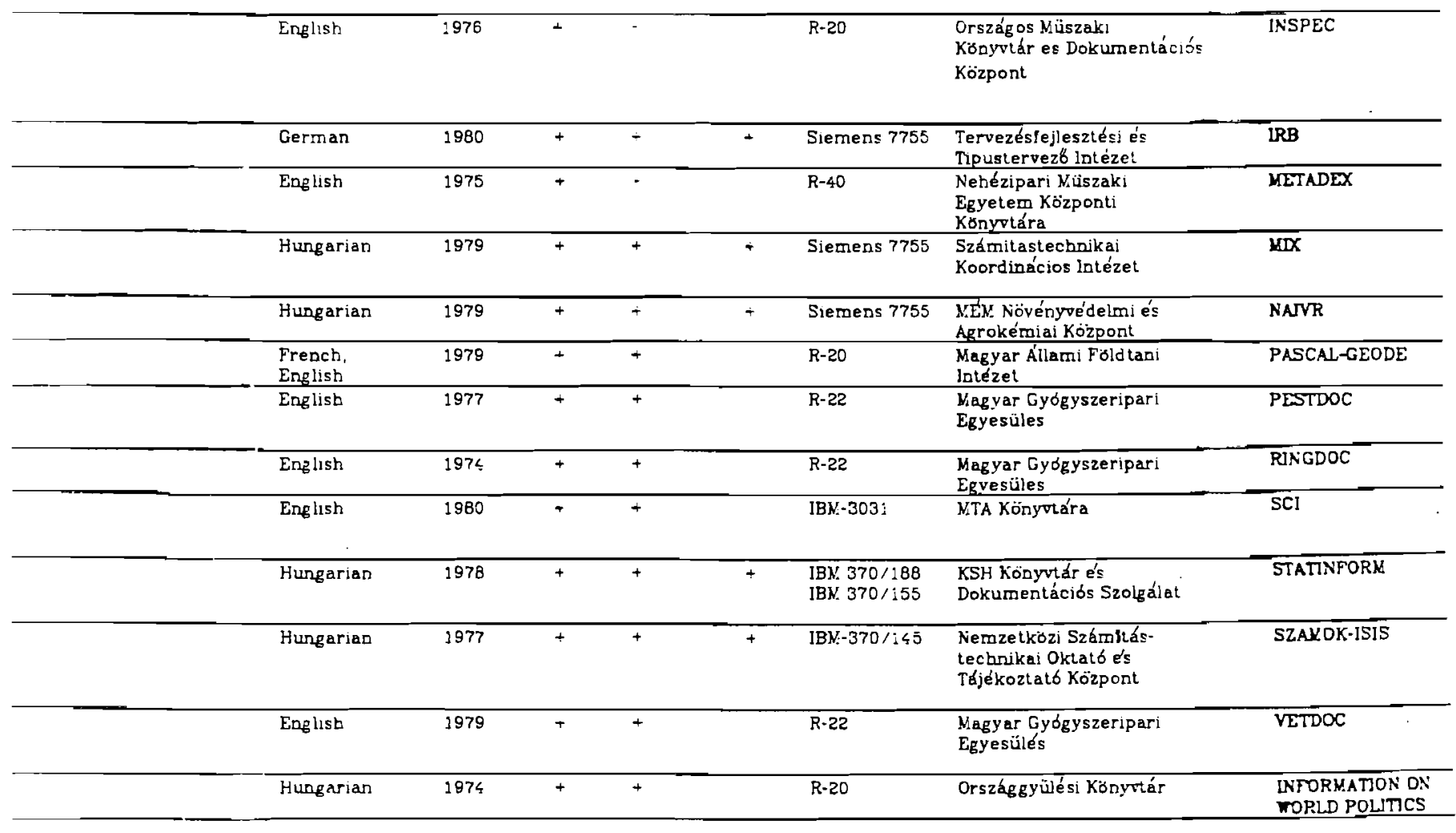


Table 2 Public database - services under preparation in Hungary (1980) (Source: [4] Dúzs. J et al. 198:)

\begin{tabular}{|c|c|c|c|c|}
\hline No & Database & Coverage & $\begin{array}{l}\text { Number of } \\
\text { records } \\
(1980 \text { data }) \\
(000 s)\end{array}$ & $\begin{array}{l}\text { New } \\
\text { records } \\
\text { in } 1980\end{array}$ \\
\hline 1. & $\begin{array}{l}\text { AlS-NISON } \\
\text { (Automated lnfor- } \\
\text { mation System of } \\
\text { Internationai) }\end{array}$ & $\begin{array}{l}\text { Economics, political sciences, } \\
\text { sociology, law, history. } \\
\text { lingistics, literature } \\
\text { critiques, orientalistics, etc. }\end{array}$ & $?$ & $?$ \\
\hline & $\mathrm{CAB}$ & $\begin{array}{l}\text { Agricultural economics and } \\
\text { policy, entormology, animal } \\
\text { breading. agricultural sciences } \\
\text { and applied biology }\end{array}$ & 1.200 & 60 \\
\hline 3. & ETK-SZAKI & $\begin{array}{l}\text { Architecture, construction, } \\
\text { tow planaing, construction } \\
\text { materials }\end{array}$ & 7 & 7 \\
\hline 4. & FRANCIS & $\begin{array}{l}\text { Philosophy, history of science } \\
\text { and technology, history and science } \\
\text { of literature, linguistics, art. } \\
\text { acheology, history and science of } \\
\text { educations, sociology, ethnology. } \\
\text { international bibliography of } \\
\text { administrative science, eaergy. } \\
\text { computer sciences. etc. }\end{array}$ & 570 & 70 \\
\hline 5. & IFIS & $\begin{array}{l}\text { Nutrition science, food } \\
\text { production and industry. } \\
\text { technology }\end{array}$ & 200 & $1 B$ \\
\hline
\end{tabular}

\begin{tabular}{llll}
\hline 6. INFORNECON Economics & 80 & 20
\end{tabular}

\begin{tabular}{lll}
\hline 7. IRL Virology, microbiology. & 100
\end{tabular}

ecology, etc.

\begin{tabular}{|c|c|c|c|}
\hline $\begin{array}{l}\text { B. IRRD } \\
\text { (International } \\
\text { Road Research } \\
\text { Documentation) }\end{array}$ & Road transportation & 100 & $i 2$ \\
\hline 9. ISDS & $\begin{array}{l}\text { International Serials Data } \\
\text { Systems (all sciences) }\end{array}$ & 140 & 25 \\
\hline $\begin{array}{l}\text { 10. (VNITT) } \\
\text { (International } \\
\text { Information } \\
\text { System of } \\
\text { Published } \\
\text { Papers) }\end{array}$ & $\begin{array}{l}\text { All published papers of the } \\
\text { world; according to the plans, } \\
\text { in } 1980 \text {; informatics, automation, } \\
\text { biology, telecommunication. } \\
\text { mining, metallurgy, etc }\end{array}$ & 700 & $?$ \\
\hline 11. $\mathrm{MNB}$ & Hungarian National Bibliography & 60 & 10 \\
\hline $\begin{array}{l}\text { 12. IJCST-SIISRS } \\
\text { (Special intl. } \\
\text { Ini. System of } \\
\text { Research } \\
\text { Projects in } \\
\text { Science) }\end{array}$ & $\begin{array}{l}\text { Research reports, doctoral } \\
\text { dissertations, thesis, reviews. } \\
\text { computer program packages } \\
\text { (coverage: general) }\end{array}$ & 76 & 39 \\
\hline $\begin{array}{l}\text { 13. WAA } \\
\text { (World } \\
\text { Aluminium } \\
\text { Abstracts) }\end{array}$ & $\begin{array}{l}\text { Aluminium industry and all } \\
\text { related topies and areas }\end{array}$ & 75 & 7 \\
\hline
\end{tabular}

- Decision to be taken later

- Coverage for 108: services 


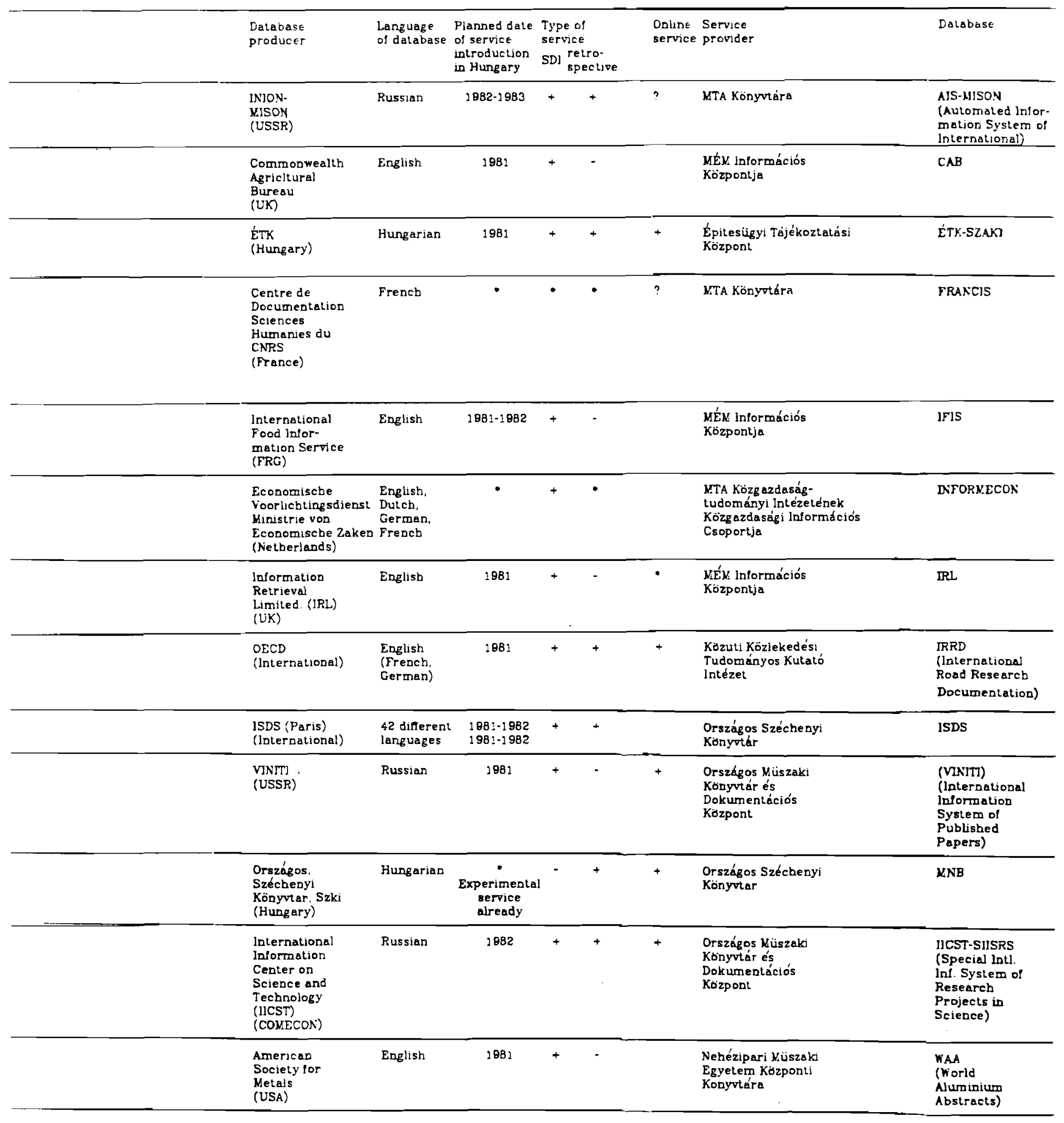


offline regime. Thus it is of no surprise that it was this industry that became the earliest interested in online services. It is also not surprising that it was because of the information needs of these industries that some special databases were produced and serviced in Hungary, especially in fields such as the ${ }^{13} \mathrm{C}$-NMR or the NAIVR databases. It is interesting to note that these database services were already implemented for online regimes well before the use of online series to foreign hosts started in Hungary.

Major databases in the field of chemistry and pharmacology in Hungary are imported in the form of magnetic tapes from the USA (such as Chemical Abstracts) and the UK (such as the DERWENT databases). These databases are basically international in their source coverage and also represent a type of "transactional record". For example, a new specific chemical structure is developed somewhere in the world, and the producer is rather interested in including his invention in, for example, Chemical Abstracts as soon as possible. A similar case is with patents and patent databases. In this sense these databases are built up to a certain degree as a result of international cooperation, they are de facto accepted by the relevant international industry and scientific communities as a common reference, an information and transaction forum that has best used widely. Up to now in many cases this development has been natural, source and even reference information is submitted from many countries into the central pool, to be collected, and widely distributed again. This philosophy is applied also in some of the major imported databases to Hungary. Through this approach not only convertible financial resources can be saved for the country, but also a type of 
interdependence between database producers and the Hungarian partners can be developed and maintained, on its one hand, as providers of source information to the database on the other hand as consumer of the "accumulated" product. Often--although this has not been the practice in Hungary yet--the national contribution to the source database becomes the national language version, e.g. the national (Hungarian) equivalent of a Chemical Abstract or DERWENT. The language of these large international databases are, for practical reasons, in the most frequently used languages in the scientific and technical literature. According to estimates $75 \%$ of the scientific and technical literature written at present worldwide is in English. This is also reflected in the language of the present major databases and is expected to remain so in the future. It is also remarkable to notice that databases produced in Hungary also follow the above philosophy: the data files that are intended exclusively. domestic use such as the bibliographical database of SZAMOK-ISIS, are in Hungarian, with Hungarian keywords, and Hungarian abstracts. This particular database contains references to literature sources available in Hungary in the field of computer science and information technology. It is actually one of the most popular databases in the country; however, because of its very nature it is less suitable for foreign users. Foreign users, if they want to find out the literature available worldwide, say, in the field of videotex, are better served by major English language databases covering this field, such as INSPEC, where they not only find the relevant information, but can also get help to order literature identified immediately from the source of primary information (e.g. journals, books) 
At present the Hungarian contributions to major international databases are in two major languages, i.e., English and Russian; sources to CMEA databases such as IICST-SIISRB and AIS-MISON are in Russian, and contribution to UN databases such as INIS and AGRIS in English.

Contribution and distribution of information to the UN and international databases is provided for within the UN system or by some specific international organization (e.g. INPADOC). To give an example of Hungary's cooperation in collection and distribution of databases of international interest, the National Technical Library and Information Center (OMKDK) coordinates all the above activities [18] for INIS. In 1980 the new INIS input worldwide was between 70-80 thousand information items, out of which the Hungarian input was $1.2 \%$ of the total. Since $82.5 \%$ of all input was provided by only seven countries, it is not surprising that the Hungarian input was the 11th largest among all. In 1980 in Hungary, 200 different journals were watched, and in addition all research reports, conference papers, patents, dissertations, etc. were under observation as well. The number of Hungarian inputs grew from only 25 items in 1970 to 951 in 1980.

Information is collected by the Hungarian INIS center in a predefined and standardized machine readable format, which is sent to the INIS Section of the IAEA to Vienna for compilation of all new information coming from all parts of the world.

The national distribution of the information of the INIS databases is also coordinated through OMKDK, which fulfills the duties of the Hungarian liaison office. 
Through this measure no separate marketing and direct user support is needed from the IAEA itself; all these functions are taken care of by the liaison office in Budapest.

There is no reason to assume that similar arrangements cannot be worked out with producers of other databases too, even if it is only on a purely commercial basis

In many cases, however, collaboration between players of the database industry and market just happens in a spontaneous way. In a time of increasing trade protectionism (both for import and export of goods and also information!), and in a time when more and more governments discover that informatics is becoming a political and strategic issue, the spontaneous, basically commerce-built, cooperations and relations are affected in an increasing way by governmental policy decisions

\subsection{General Growth Figures of the Hungarian Database Industry}

The database industry is worldwide one of the most dynamically growing sectors, it stands even the comparison with the rapidly expanding computer industry. In Hungary the number of public databases grew from 14 in 1979 to 25 in 1981 with a growth rate of almost $78 \%$ in this two year period. The number of service providers grew from 14 in 1979 to 20 in 1981 , a rate of $43 \%$ for the same two year period. A list of Hungarian information service providers is given in Table 3 . The relatively large number of service providers for a country with only 10 million inhabitants and moderately developed industry might be surprising at first glance. Among the 20 service centers that provide data services, most are major libraries and documentation centers with long traditions in these discip- 
Table 3. Hungarian public database service providers and list of their database services (source : $\leqslant$ ] Duzs et al. :98:)

\begin{tabular}{|c|c|c|}
\hline \multirow{2}{*}{ No. Name of the Institute } & \multirow{2}{*}{$\begin{array}{l}\text { rovider } \\
\text { Disciplire of the Irstitute }\end{array}$} & \multirow{2}{*}{ Database } \\
\hline & & \\
\hline \multicolumn{2}{|c|}{$\begin{array}{r}\text { 1. Épitésügyi Iájékoztatási Kozport Information certer } \\
\text { corstruction indlistry }\end{array}$} & ETK-SZAKI \\
\hline 2. KG Informatik & $\begin{array}{l}\text { informatior center, } \\
\text { metallurgy, machine } \\
\text { industry }\end{array}$ & AOBIPD \\
\hline $\begin{array}{l}\text { 3. Központi Statisztikai Hivatal } \\
\text { Könyvtár és Dokumentációs } \\
\text { Szolgátat }\end{array}$ & $\begin{array}{l}\text { Library and doctmer- } \\
\text { tation service, Cer.tral } \\
\text { Statistical Office }\end{array}$ & STATINFORY \\
\hline $\begin{array}{l}\text { 4. Kózuti Közlekedési MLdomáryos } \\
\text { Kutató Intézet }\end{array}$ & $\begin{array}{l}\text { Research Irstitute, } \\
\text { road transpcrtatior }\end{array}$ & IRRD \\
\hline 5. Magyar Állami Föidtari Intézet & Geology Ir.stituite & PASCAL-GEODE \\
\hline 6. Magyar Gyógyszeripari Egyesïlés & $\begin{array}{l}\text { Hurgariar. Pharma- } \\
\text { industry Associatior }\end{array}$ & $\begin{array}{l}\text { AGDOC } \\
\text { CRDS } \\
\text { FARMDOC } \\
\text { PESTDOC } \\
\text { RINGDOC } \\
\text { VETDOC } \\
\end{array}$ \\
\hline $\begin{array}{l}\text { 7. Nagyar Iudomáryos Akadémia } \\
\text { Kóngutára }\end{array}$ & $\begin{array}{l}\text { Library of the } \\
\text { Hungarian Acadeny } \\
\text { of Sciences }\end{array}$ & $\begin{array}{l}\text { AIS-VISON } \\
\text { SCI } \\
\text { FRANCIS }\end{array}$ \\
\hline $\begin{array}{l}\text { 8. Magyar iLdományos Akadémia } \\
\text { Kozgazdasági Információs } \\
\text { Szolgálata } \\
\end{array}$ & $\begin{array}{l}\text { Irformation Center on } \\
\text { Eccromy, Hungariar } \\
\text { Academy of Sciences }\end{array}$ & INFORVECON \\
\hline $\begin{array}{l}\text { 9. Magyar Tudományos Akadémia } \\
\text { Központi Kémiai Kutató } \\
\text { Intézet }\end{array}$ & $\begin{array}{l}\text { Central Ctemical } \\
\text { Research Institute, } \\
\text { Hungariar. Acaderny of } \\
\text { Sciences } \\
\end{array}$ & $\begin{array}{l}\mathrm{CCDB} \\
{ }^{13} \mathrm{C}-\mathrm{NMR}\end{array}$ \\
\hline $\begin{array}{l}\text { 10. Mezógazdasági es Élelmezésügyi } \\
\text { Minisztérium Irformációs } \\
\text { Központja }\end{array}$ & $\begin{array}{l}\text { Information Center, } \\
\text { Winistry for Agricul- } \\
\text { ture and Food }\end{array}$ & $\begin{array}{l}\text { AGRIS } \\
\text { SAB } \\
\text { IFIS } \\
\text { IRL }\end{array}$ \\
\hline $\begin{array}{l}\text { 11. Mezćgazdasági es Élelmezesügyi } \\
\text { Minisztérium Növenyvédelmi } \\
\text { és Agrokérniaj Központ }\end{array}$ & $\begin{array}{l}\text { Plant protection and } \\
\text { Agrochemical Center. } \\
\text { Wiristry for Agricul- } \\
\text { ture and Food }\end{array}$ & NAJR \\
\hline $\begin{array}{l}\text { i2. Nehézipari Müszaki Egyetem } \\
\text { Közporti Köryvtára }\end{array}$ & $\begin{array}{l}\text { Certrai Lıbrary, } \\
\text { Unversity for Heavy } \\
\text { Industry, Miskolc } \\
\end{array}$ & $\begin{array}{l}\text { VETADEX } \\
\text { WAA }\end{array}$ \\
\hline $\begin{array}{l}\text { 13. Venzetkózi Számitastechnikai } \\
\text { Oktató és Jájékoztató } \\
\text { Közport } \\
\end{array}$ & $\begin{array}{l}\text { Irternaticnal Edvea- } \\
\text { tion and Irformatior. } \\
\text { Center or. Complitirg }\end{array}$ & SZAVOK-ISIS \\
\hline :4 Országgyülésı Köryvtár & $\begin{array}{l}\text { Library of the } \\
\text { Parliamert }\end{array}$ & $\begin{array}{l}\text { INFORYATION } \\
\text { ON WORLD } \\
\text { POLITICS }\end{array}$ \\
\hline $\begin{array}{l}\text { \$5. Országos Miszaki Könyutár } \\
\text { és Dokumentácios } \\
\text { Kózpont }\end{array}$ & $\begin{array}{l}\text { National Technical } \\
\text { Library and } \\
\text { Documentation. Center }\end{array}$ & $\begin{array}{l}\text { COMPENDEX } \\
\text { INIS } \\
\text { INSPEC } \\
\text { MISOD } \\
\text { IICST-SIISRS } \\
\end{array}$ \\
\hline :6. Orszagos Széchenyi Könyvtár & National Library & $\begin{array}{l}\text { ISDS } \\
\text { MNB }\end{array}$ \\
\hline 17. Országos Vezetöképzô Kozport & $\begin{array}{l}\text { National Maragement } \\
\text { Training Center }\end{array}$ & BIBDOSZ \\
\hline $\begin{array}{l}\text { 18. Számitastechnikai Koordinációs } \\
\text { Latezet }\end{array}$ & $\begin{array}{l}\text { Institute for Coordi- } \\
\text { nation of Computer } \\
\text { Technigues }\end{array}$ & $\mathrm{VIX}$ \\
\hline $\begin{array}{l}\text { 99. Tervezésiejiesztési és } \\
\text { Tipustervezó Intézet }\end{array}$ & $\begin{array}{l}\text { Plarring Bureat, Construc } \\
\text { tion \& Buildirg }\end{array}$ & - IRB \\
\hline $\begin{array}{l}\text { 20. Veszpréni Vegyipari Egyetem } \\
\text { Központi Köryytára }\end{array}$ & $\begin{array}{l}\text { Certral Library of the } \\
\text { Chemical Lriversity } \\
\text { of Veszprea }\end{array}$ & $\begin{array}{l}\text { CA SEARCH } \\
\text { CIN }\end{array}$ \\
\hline
\end{tabular}


lines. Some of them are relatively recently created specialized information centers, research institutes, educational centers, and industry associations. According to Table 3 most of the centers are only operating a few databases, the maximum number bring six. The reason for this is twofold. First of all the service centers in Hungary are rather specialized in their disciplines, which has obvious advantages and disadvantages. One advantage is that by concentrating on one or two disciplines they can satisfy special user requirements and, in addition, in many cases they are also the source of the primary document identified. SZÁMOK - the International Education and Information Center on Computing-- runs a moderately large bibliographic database containing references of its own extensive library. The often heard disadvantage of distributed service provider centers is the unnecessary multiplication of resources such as hardware, software and man-power. Nonetheless, in a Hungarian type of environment the distributed type of information and database centers seem to be better suited.

Only a few illustrative figures concerning the growth rates of database users will be given here.

Table 4 shows the number of users served for selected databases. In general--taking into account that Hungary is a small country--the number of customers for some of the databases is remarkably high. Very specialized databases, such as CCDB, ${ }^{13} \mathrm{C}-\mathrm{NMR}$ or PASCAL-GEODE have only a few customers. The DERWENT databases are only used--due to their special arrangement with the database supplier--by a few companies of the pharmaceutical industry, but the usage of the classical bibliographic databases such as INIS, or INSPEC, etc, are not at all low. If one takes into 
Table 4. Selected public databases serviced in Hungary (1980 data) according to their customer institutions served (Source: [4])

\begin{tabular}{|c|c|c|c|c|c|c|c|c|}
\hline \multirow[t]{2}{*}{$\begin{array}{l}\text { Name of } \\
\text { database }\end{array}$} & \multirow[t]{2}{*}{$\begin{array}{l}\text { Country of } \\
\text { origin }\end{array}$} & \multicolumn{3}{|c|}{$\begin{array}{l}\text { Number of customer } \\
\text { institutions served }\end{array}$} & \multirow{2}{*}{$\begin{array}{l}\text { Number of } \\
\text { recordis } \\
\text { (1980 data) }\end{array}$} & \multicolumn{2}{|c|}{$\begin{array}{l}\text { Cost of service } \\
\text { in Hungary }\end{array}$} & \multirow{2}{*}{$\begin{array}{l}\text { Information } \\
\text { retrieval } \\
\text { software } \\
\text { package used }\end{array}$} \\
\hline & & SDI & Retrospective & Total & & SDI & Retrospective & \\
\hline AGDOC & UK & 6 & 7 & 7 & 100,000 & $\mathrm{AL}^{3)}$ & $\mathrm{AL}$ & $\begin{array}{l}\text { DERWENT } \\
\text {-ROBINS }\end{array}$ \\
\hline AGRIS & UN(FAO) & 14 & $?$ & 14 & 600,000 & $6000 \mathrm{Ft} / \mathrm{yr}$ & $A \cup$ & BINAR \\
\hline AOBIPD & $\begin{array}{c}\text { USSR } \\
\text { (CONECON) }\end{array}$ & 5 & 5 & 5 & $4,500,000$ & $\mathrm{AU}$ & $A L$ & PA(own) \\
\hline CA SEARCH & USA & 99 & $\cdot$ & 99 & $3.500,000$ & $\begin{array}{c}10000 \mathrm{Ft} / \mathrm{yr} \\
+\mathrm{AU}\end{array}$ & - & BINAR \\
\hline $\mathrm{CCDB}$ & UK & 3 & 3 & 3 & 28,000 & $\mathrm{AL}$ & $\mathrm{AL}$ & $\mathrm{CCDB}$ \\
\hline CIN & USA & 7 & 7 & 7 & 340.000 & $\begin{array}{c}9000 \mathrm{Ft} / \mathrm{yr} \\
+\mathrm{AU}\end{array}$ & $\begin{array}{c}9000 \mathrm{Ft} / \mathrm{yr} \\
-\mathrm{AU}\end{array}$ & $\begin{array}{l}\text { (own } \\
\text { development) }\end{array}$ \\
\hline 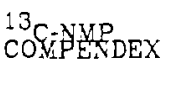 & $\begin{array}{l}\text { HUNGARY } \\
\text { LSA }\end{array}$ & 29 & 8 & $\begin{array}{r}8 \\
29\end{array}$ & $\begin{array}{r}26.000 \\
970,000\end{array}$ & $\begin{array}{c}\mathrm{AU} \\
6000 \mathrm{Ft} \\
\left.+\mathrm{AU}^{1}\right\rangle \mathrm{yr}\end{array}$ & $\stackrel{\mathrm{AL}}{\cdot}$ & $\begin{array}{l}\text { CNRSYS } \\
\text { BINAR }\end{array}$ \\
\hline CRDS & UK & 6 & 7 & 7 & 38,000 & $\mathrm{AL}$ & $A L$ & $\begin{array}{l}\text { DERWENT- } \\
\text { ROBINS }\end{array}$ \\
\hline FARYDOC & UK & 6 & 7 & 7 & 140,000 & AL & $\mathrm{AL}$ & $\begin{array}{l}\text { DERWENT- } \\
\text { ROBLS }\end{array}$ \\
\hline INIS & $\begin{array}{c}\text { UN } \\
\text { (IAEA) }\end{array}$ & 20 & $16^{2)}$ & $3 c$ & 572,000 & $\begin{array}{c}6000 \mathrm{Ft} / \mathrm{yr} \\
\left.-\mathrm{AU}^{1}\right)^{3}\end{array}$ & $A L^{\top}$ & BINAR \\
\hline INSPEC & $\mathrm{UK}$ & 49 & experimental & $\leq 9$ & $1,500,000$ & $\begin{array}{l}6000 \mathrm{Ft} / \mathrm{yr} \\
+\mathrm{AU}^{1)}\end{array}$ & $\mathrm{AU}$ & BINAR \\
\hline $\begin{array}{l}\text { IRB } \\
\text { METADEX }\end{array}$ & $\begin{array}{l}\text { FRG } \\
\text { UK }\end{array}$ & $\begin{array}{l}17 \\
18\end{array}$ & $: 7$ & $\begin{array}{l}17 \\
18\end{array}$ & $\begin{array}{r}20.000 \\
450.000\end{array}$ & $\begin{array}{c}\mathrm{AU} \\
8000 \mathrm{Ft} / \mathrm{yr}\end{array}$ & $\mathrm{AU}$ & $\begin{array}{l}\text { GOLEM } \\
\text { BINAR }\end{array}$ \\
\hline $\begin{array}{l}\text { PASCAL- } \\
\text { GEODE }\end{array}$ & FRANCE & 4 & 4 & 4 & 260,000 & free & free & BINAR \\
\hline PESTDOC & UK & 6 & 7 & 7 & 90,000 & $A U$ & $\mathrm{AU}$ & $\begin{array}{l}\text { DERWENT- } \\
\text { ROBIS }\end{array}$ \\
\hline RINGDOC & UK & 6 & $?$ & 7 & 600,000 & $\mathrm{AU}$ & $\mathrm{AU}$ & $\begin{array}{l}\text { DERWENT- } \\
\text { ROB1S }\end{array}$ \\
\hline STATINFORY. & HUNGARY & $: 7$ & 2 & 19 & 20,150 & $\begin{array}{l}3000 \mathrm{FT} / \mathrm{yr}- \\
5000 \mathrm{Ft} / \mathrm{yr}\end{array}$ & $5000 \mathrm{Ft} / \mathrm{yr}$ & TEX-P.AC \\
\hline SZAYOK-ISIS & HLNGARY & 22: & 221 & 22: & 46,000 & $\begin{array}{l}3000 \mathrm{Ft} / \mathrm{yr}^{-} \\
4000 \mathrm{Ft} / \mathrm{yr}\end{array}$ & $\begin{array}{l}4000 \mathrm{Ft} / \mathrm{yr}^{-} \\
5000 \mathrm{Ft} / \mathrm{yr}\end{array}$ & ISIS \\
\hline VETDOC & UK & 6 & 7 & 7 & 54,000 & $A L$ & $\mathrm{AL}$ & $\begin{array}{l}\text { DERWENT- } \\
\text { ROBINS }\end{array}$ \\
\hline $\begin{array}{l}\text { INFORMATION } \\
\text { ON WORLD } \\
\text { POLITICS }\end{array}$ & HL'NGARY & 250 & 30 & 250 & 18.000 & $7200 \mathrm{Ft} / \mathrm{yr}$ & $A L^{\circ}$ & $\begin{array}{l}\text { (own } \\
\text { development) }\end{array}$ \\
\hline
\end{tabular}

\footnotetext{
i) over 1000 items/yr according to usage

2) online to the IAEA computer in Vienna

3) $\mathrm{AU}=$ according to usage
} 
account that these statistics were assembled at a time when these databases were serviced in an offline regime, which has since changed, then the extent of the meaning of these figures is even better. The most "popular" foreign database is at present--as one could have expected-Chemical Abstracts with about hundred customer institutions. However, surprisingly (or perhaps not), of the two most widely used databases within the customer community are Hungarian: one being the bibliographical online database of SZÁMOK and the other a database on INFORMATION OF WORLD POLICY MATTERS--produced by the Library of the Parliament. Both databases had, at the time of sampling, more than 200 customers each,

The "customer growth" rates for the two years between 1979 and 1981 are shown in Table 5 for some selected databases.

Table 5. Growth rates of customer institutions (between 1979 and 1981) for some selected databases serviced in Hungary [4]

\begin{tabular}{l|c|c|c}
$\begin{array}{c}\text { Name of } \\
\text { the database }\end{array}$ & $\begin{array}{c}\text { No, of customer } \\
\text { institutions } \\
\text { in } 1979\end{array}$ & $\begin{array}{c}\text { No. of customer } \\
\text { institutions } \\
\text { in 1981 }\end{array}$ & $\begin{array}{c}\text { Growth rates } \\
\text { for two } \\
\text { years [\%] }\end{array}$ \\
\hline CA SEARCH & 98 & 99 & 1 \\
INIS & 11 & 34 & 209 \\
INSPEC & 56 & 49 & -14 \\
METADEX & 17 & 18 & 6 \\
SZAMOK-ISIS & 145 & 221 & 52 \\
INFORMATION ON & 150 & 250 & 67 \\
WORLD POLITICS & & & \\
\hline
\end{tabular}

From these few figures the following can be deduced: as mentioned above at the time of sampling CA SEARCH, INSPEC and METADEX were retrieved in offline mode and only in SDI regime. All services started at 
the beginning and middle of the seventies, thus when the statistics were taken they were already well established and saturated. Online service to foreign database hosts was only introduced around the 1980 sampling, it is not yet known how many new customers were attracted by this type of service, how many old customers switched over from offline SDI to online, or how many took SDI online as a new form of service in addition to offline. INIS is actually the only database in the sample that became online during the sampling period 1979-1981. In the case of INIS this resulted in of 14 new customer organizations joining this service, and some old customer organizations also took the opportunity of getting online services. The customer growth figures of the most "popular" databases SZAMOKISIS and the one on World Politics also had very high rates.

\subsection{Cost of Database Usage}

There is no single pricing policy for database usage in Hungary-as anywhere else in the world. As an orientation for pricing policy and cost level, data were also collected in [4]. These data, however, should be used as general information; for the current prices it is best to contact the contact points and persons that are also listed in [4].

In general one may say that the pricing practices in Hungarian services are very similar to those of other countries.

The majority of services sampled in [4] were offline services, and in particular SDI. For the majority of such services, as shown in Table 4, a yearly subscription fee has to be paid, which is, for example, in the case of CA SEARCH, $10000 \mathrm{Ft} /$ year (approximately AS 5000/year) or for INSPEC, INIS, METADEX, etc. $6000 \mathrm{Ft} /$ year per profile. In addition to 
these costs customers have to pay for each found and printed item, which in the case of CA SEARCH is $28 \mathrm{Ft} /$ item, and in the case of INSPEC, INIS, METADEX, etc. $10 \mathrm{Ft} /$ item, however the first 1000 items/profile are always free of charge for this second group.

It has to be mentioned that although the database service organizations pay their subscription fees for foreign, non CMEA databases, in convertible currencies, such as US\$. Hungarian users pay in Hungarian currency.

Hungarian databases are usually cheaper. SZAMOK requires for its ISIS database between 3000 and $4000 \mathrm{Ft} /$ year from its customers, the Library of the Parliament 7200 Ft/year. No separate charges for selected and printed items are requested.

A large number of database services are charged according to the measured resources used, especially in computer time.

Charges for online foreign services are not included in [4], since they basically became operational after the sampling point in early 1981. In principle one can say, however, that they follow the pricing practices used in North America and Western Europe quite closely. Users have to pay to foreign online database service centers in convertible currencies. As is well known, a part of that payment is in the form of royalties to the producer of the particular database used and the rest is kept by the data center operator as revenue for providing his services. In addition, users have to pay for the used telecommunication resources as well. If the connection was made through the public switched telephone network, the Hungarian PTT collects the revenue for the long distance call, if the Hun- 
garian data network NEDIX is used for connection, again the Hungarian PTT collects all revenues, even for the foreign part of the data communication channel. A similar case is when a user decides to establish a leased line connection to a foreign data center. All these expenses are collected by the PTT in Hungarian currencies.

Thus, from the financial point of view, when establishing access to foreign database hosts the only "critical" part in the chain of administrative matters in Hungary is the agreement between host and customer. Since it is a foreign trade agreement, with obligations in foreign currencies, it necessitates special administrative, and contractual steps, even for the most simplest form of agreement, such as the establishment of a no-cost, open ended account number and user name on a foreign database computer.

For this, and obvious other known reasons for having so-called, intermediary services, a few companies in Hungary have already taken up the task of serving the database community with "information broker" services. These organizations help users to identify which database is best suited to their purposes and which data hosts to work with. They will also introduce users to online services in general, provide consultancy on the databases and the systems, or provide terminal equipment to the users. In addition to these services they can take over the burden of all--sometimes complicated and time-consuming-- administrative procedures, which they can cut down considerably. There are also intermediaries who require payment in local currency which is most convenient for users short of convertible currency. One advantage of these intermediaries is that they are better able to establish more favorable 
deals and conditions with the suppliers of database services, such as lower rates for the bulk use of data, or take over marketing, educational activities, etc., for them in Hungary. The variety of collaboration between foreign database supplier and Hungarian intermediaries can actually be very diverse and broad.

Nonetheless, foreign online services in Hungary are not the cheapest. In some applications, however, e.g. when specific information is promptly required, or information with high update frequency is sought foreign online services are essential.

One of the major uses of online services to foreign database service centers is when access to a database has to be made, that is not serviced in Hungary. There are in total some 1000 public databases around the world, some of which are of international interest and importance, but the majority of which serve only local needs. This is the case with the majority of the Hungarian databases. Among databases of international interest a certain number of them are of primary interest for a given country. There is a certain point in the "cost" and "benefit" analysis for each database where it is better to buy and install the database within the country rather than to access it on foreign database hosts. There are, for example, simple economic factors that decide when it is better to become a subscriber to a database, loading the magnetic tape of the database onto a data center in the country to serve domestic users as opposed to subscribing to foreign database services and paying for these services and the long distance data communication charges. There are also many databases however that need to be accessed only now and then or are expensive, very special services, let us say, requiring heavy 
hardware and software installments not residing in the county. To put these data files onto national systems is hardly justified. In some countries nowadays there is, after economical and technical applications, a trend to take political considerations into account as well. There are countries that prefer to install foreign databases of interest to their own data center rather than allow domestic users to access data centers abroad. The main argumentation is that dependence on foreign data services increases the vulnerability of the serviced country and is, in addition, negative for the balance of payments and for the domestic labor market.

In Hungary major considerations along the se lines fall only into the category of technical and economical applications. Since both the purchase of a particular database, or the signing of a standard form agreement for online services, fall into the category of foreign trade, where governmental authorities are involved to grant import licenses, the implementation of a governmental information policy is also provided for through this channel. "Transactional" databases--such as patents, commodity and stock exchange market, and news agencies' databases-obviously should not be included in this category. They are by their nature often better accessed through a worldwide network.

\subsection{Origin of Databases Serviced Publicly in Hungary}

Tables 1, 2, and 6 show the origin of databases publicly serviced in Hungary together with their regional distribution. The first database publicly serviced--introduced in 1970--was the FARMDOC (DERWENT) database from the UK. The first public service of a Hungarian database (INFORMA- 
TION on WORLD POLITICS) started four years later, in 1974. By 1979--when the first major sampling of the Hungarian databases was taken there were 14 databases serviced. According to the number of databases the majority originated in Western Europe, followed by Hungarian databases. The CMEA, the International Organizations and the USA being represented by one database each.

At the time of the second sample in early 1981, the share of West European databases was still the largest, followed by the increasing number of domestic databases (Table 6). The share of the US databases and of the international organizations has increased too. By 1983 it is expected that the weight of CMEA databases will also have increased.

In the long run it can be anticipated that first of all the share of the domestic and CMEA databases will grow. It can still be presumed that the share of West European databases will remain high. Many of these databases are international in their nature and importance and it can be expected that with some of the database procedures cooperative efforts in collecting input materials will be strengthened.

As to the size of databases, the general trend can be observed that the purely Hungarian databases are small to medium in size; some other specialized foreign databases are also proportionally small. Databases of international organizations such INIS or AGRIS--which came into being as a result of international cooperation--are between medium and large. The same is true for the bibliographical databases, such as COMPENDEX, METADEX, INSPEC, DERWENT and others. In this category of databases of international interest, arrangements are known in which national input is provided locally. The largest "mammoth" type of databases are foreign 
Table 6. Databases publicly serviced in Hungary according to their origin (Source: [4] Dúzs et al. 1981).

\begin{tabular}{|c|c|c|c|c|c|}
\hline & DOMESTIC & CMEA & $\begin{array}{l}\text { Inter- } \\
\text { national }\end{array}$ & $\begin{array}{l}\text { West- } \\
\text { European }\end{array}$ & $\begin{array}{l}\text { North- } \\
\text { American }\end{array}$ \\
\hline $\begin{array}{l}\text { 0/ Database } \\
\text { services } \\
\text { operation } \\
\text { (1st half of } \\
1879)\end{array}$ & $\begin{array}{l}\text { BIBDOSZ } \\
\text { SZAMOK-ISIS } \\
\text { INFORMATION } \\
\text { ON WORLD } \\
\text { POLITICS }\end{array}$ & AOBIPD & INIS & $\begin{array}{l}\text { AGDOC } \\
\text { CRDS } \\
\text { RINGDOC } \\
\text { PESTDOC } \\
\text { VETDOC } \\
\text { FARMDOC } \\
\text { INSPEC } \\
\text { METADEX }\end{array}$ & CA SEARCH \\
\hline $\begin{array}{l}\text { ad 0/Total: } \\
14(100 \%)\end{array}$ & $3(22 \%)$ & $1(7 \%)$ & $1(7 \%)$ & $8(57 \%)$ & $1(7 \%)$ \\
\hline $\begin{array}{l}\text { 1/ Database } \\
\text { services in } \\
\text { operation } \\
\text { (1980 end) }\end{array}$ & $\begin{array}{l}\text { BIBDOSZ } \\
13 \text { C-NMR } \\
\text { MLX } \\
\text { NAIVR } \\
\text { STATINFORM } \\
\text { SZAMOK-ISIS } \\
\text { INFORMATION } \\
\text { ON WORLD } \\
\text { POLITICS }\end{array}$ & AOBIPD & $\begin{array}{l}\text { AGRIS } \\
\text { INIS }\end{array}$ & $\begin{array}{l}\text { AGDOC } \\
\text { CCDB } \\
\text { CRDS } \\
\text { FARMDOC } \\
\text { INSPEC } \\
\text { IRB } \\
\text { METADEX } \\
\text { PASCAL- } \\
\text { GEODE } \\
\text { PESTDOC } \\
\text { RINGDOC } \\
\text { VETDOC } \\
\end{array}$ & $\begin{array}{l}\text { CA SEARCH } \\
\text { CIN } \\
\text { COMPENDEX } \\
\text { SCI }\end{array}$ \\
\hline $\begin{array}{l}\text { ad } 1 / \text { Total: } \\
25(100 \%)\end{array}$ & $7(28 \%)$ & $1(4 \%)$ & $2(8 \%)$ & $11(44 \%)$ & $4(16 \%)$ \\
\hline $\begin{array}{l}\text { 2/ Database } \\
\text { services } \\
\text { under } \\
\text { preparation } \\
\text { (1980 end) }\end{array}$ & $\begin{array}{l}\text { ETK-SZAKI } \\
\text { MNB }\end{array}$ & $\begin{array}{l}\text { AIS-MISON } \\
\text { MISOD } \\
\text { IICST-SIISRS }\end{array}$ & ISDS & $\begin{array}{l}\text { CAB } \\
\text { FRANCIS } \\
\text { IFIS } \\
\text { INFORMECON } \\
\text { IRL } \\
\text { IRRD } \\
\end{array}$ & WAA \\
\hline $\begin{array}{l}\text { ad 2/Total: } \\
13(100 \%)\end{array}$ & $2(15 \%)$ & $3(23 \%)$ & $1(8 \%)$ & $6(46 \%)$ & $1(8 \%)$ \\
\hline $\begin{array}{l}\text { Grand total: } \\
\quad 38[1+2](100 \%)\end{array}$ & $9(24 \%)$ & $4(10 \%)$ & $3(8 \%)$ & $17(45 \%)$ & $5(13 \%)$ \\
\hline
\end{tabular}


ones, and probably they will be that way for a long time. Two of them are North-American and one Eastern-European. All databases are, to a certain extent, of a "transactional" nature: SCI Science Citation Index-contains who cited whom, where and when; AOBIPD (on multidisciplinary patents) contains who patented what, when and where; Chemical Abstracts, to a certain extent, also belongs to this category. It would be an illusion to think that databases of this sort and kind should be generated solely by small countries such as Hungary.

\subsection{Computer Hardware and Systems Software Used}

Table 1 shows that when the "snapshot" of statistics was taken the majority of the database service centers used computer systems belonging to the Ryad series--computer systems produced in CMEA countries. Out of the computer systems employed, 16 belong to the category of the so-called Ryad I series, one already to the category of Ryad II. The rest of the computer systems applied originated from Western Europe and North America: the 5 IBM mainframes used are similar in their hardware and software architecture to the Ryad series; in addition, one Siemens, one ICL, and one Honeywell / Bull system were servicing databases.

The actual services that were provided at the time of sampling (end of 1980) were in close relation to the characteristics and performance categories of the computer mainframes used. The majority of the services--as we pointed out earlier--were SDI (each database had an SDI service), retrospective services being provided for $80 \%$ of the databases; the remaining 20\% included just the largest ones, such as CA SEARCH, COMPENDEX, INSPEC and METADEX and had only SDI services. For INIS 
this type of service was not so critical, since online access from Hungary to the IBM 3033 data center of the International Atomic Energy Agency (IAEA) was already usual practice at the time of sampling. This service actually eliminated any need for a similar service on a Hungarian host. Online services--although growing in their numbers--were outweighted at the end of 1980 by offline services. In 1980 only $36 \%$ of the publicly serviced databases had an online service option. Looking at the computer systems applied it can be seen that all online services were provided on time sharing systems. Time sharing, however, could be provided only on major West European and North American systems and on the computers of the emerging Ryad II computer series. In 1980, however, the delivery of Ryad II had just started, and this is fairly reflected in the statistics of Table 1. Thus, the majority of database services were provided on computers working with batch oriented operation systems, such as the R-20 and R-22 computers, which were not only the most commonly used systems for database services, but also for other computer applications in general during the second half of the seventies.

The R-20 and R-22 computers (produced in the USSR and Bulgaria) have, in this respect, other unfavorable characteristics that do not allow them to become ideal database service computers. This first of all lies in their relatively low online disc storage and main memory capacity. All in all they are too small to be ideal for database services. The R-20 has a maximum core capacity of 250 KBytes (the R-22 of 500 KBytes), allowing on each their two selector channels the linkage of one disc-and one tape controller. The most suitable disc controller (ES-5561) allows the connection of maximum 8 (ES-5061) disc drives, each of 29 MByte capacity (in 
total 232 MByte).

The $\mathrm{R}-40$ produced in the German Democratic Republic is larger and thus more suitable for database services. Its main memory is built in 256 KByte modules, with a maximum capacity of $1 \mathrm{MB}$. It offers a one byteMUX channel for low speed peripherals such as discs. These channels can support up to 8100 MByte disc drives (ES-5066)--produced by the USSR.

For the theoretically available maximum of 5 selector channels, if one selector is kept reserved for tape devices, 4 GByte secondary storage (disc) could be attached to the system--using 5 ES-5566 disc controllers with each 8 ES-5066 drives.

The 100 MByte discs, however, have only been in production since the end of the seventies--actually they already belong to the category of the Ryad II series--which had not yet reached its full market penetration when the database sample was taken in Hungary at the end of 1980 , early 1981. Thus the $R-40 \mathrm{~s}$ in use for database services had much less disc capacity, using mainly 29 MByte disc drives.

As to the question why in 1980-1981 offline database services had such weight in Hungary, and why $R-20$ and $R-22$ computers were used for database services if they were only of limited use, one has to look at the development of the Hungarian computer population as a whole. Tables 79 show the development of the Hungarian computer population [3] without mini- and microcomputer systems. Table 7 shows that in 1979 only 4.3 percent of the computer population was, with regard to the size of the computer (medium-large, large), really suitable for providing database services of this kind. On the medium-size computers--which 
Table 7. Time series of computer installations in Hungary according to their performance categories* (end of the year data). (Source: [3] 1981, Szamitastechnikai Statisztikai Evkonyv 1980)

\begin{tabular}{|c|c|c|c|c|c|c|c|c|}
\hline $\begin{array}{l}\text { Computer performance } \\
\text { category }\end{array}$ & 1960 & 1965 & 1970 & 1975 & 1976 & 1977 & 1978 & 1979 \\
\hline & \multicolumn{8}{|c|}{ (pieces) } \\
\hline Small computers & 5 & 16 & 42 & 219 & 272 & 322 & 372 & 419 \\
\hline Small-medium & - & 5 & 48 & 32 & 32 & 30 & 30 & 28 \\
\hline Medium & - & - & 29 & 118 & 133 & 150 & 163 & 171 \\
\hline Medium-large & - & - & 1 & 12 & 16 & 17 & 21 & 26 \\
\hline Large mainframes & - & - & - & 1 & 1 & 2 & 2 & 2 \\
\hline \multirow{3}{*}{$\begin{array}{l}\text { Total } \\
\text { Index: } \\
\text { year } 1970=100.0\end{array}$} & 5 & 21 & 120 & 382 & 454 & 521 & 588 & 646 \\
\hline & 4.2 & 17.5 & 100.0 & 318.3 & 378.3 & 434.2 & 490.0 & 538.3 \\
\hline & \multicolumn{8}{|c|}{$(\%)$} \\
\hline Small computers & 100.0 & 76.2 & 35.0 & 57.3 & 59.9 & 61.8 & 63.3 & 64.9 \\
\hline Small-medium & - & 23.8 & 40.0 & 8.4 & 7.1 & 5.7 & 5.1 & 4.3 \\
\hline Medium & - & - & 24.2 & 30.9 & 29.3 & 28.8 & 27.7 & 26.5 \\
\hline Medium-large & - & - & 0.8 & 3.1 & 3.5 & 3.3 & 3.6 & 4.0 \\
\hline Large mainframes & - & - & - & 0.3 & 0.2 & 0.4 & 0.3 & 0.3 \\
\hline \multirow[t]{2}{*}{ Total: } & 100.0 & 100.0 & 100.0 & 100.0 & 100.0 & 100.0 & 100.0 & 100.0 \\
\hline & \multicolumn{8}{|c|}{ Value in Forints } \\
\hline $\begin{array}{l}\text { Value of all computer } \\
\text { installations } \\
\text { (Billion } \mathrm{Ft} \text { ) }\end{array}$ & .. & . & 2.1 & 7.5 & 9.4 & 11.4 & 12.6 & 13.8 \\
\hline $\begin{array}{l}\text { Value of an average } \\
\text { computer installation } \\
\text { (Million } \mathrm{Ft} \text { ) }\end{array}$ & $\cdot$. & . & 17.3 & 19.6 & 20.8 & 21.8 & 21.4 & 21,4 \\
\hline
\end{tabular}

- without mini- and microcomputer systems 
Table B. Number of computers in Hungary (data end of 1979) according to the origin of computers and their performance categories. (Source: [3] 1981. Szamitastechnikai Statisztikai Evkonyv 1980).

\begin{tabular}{|c|c|c|c|c|}
\hline $\begin{array}{l}\text { Computer } \\
\text { performance } \\
\text { category }\end{array}$ & Total: & $\begin{array}{l}\text { Out of the } \\
\text { Hungary }\end{array}$ & $\begin{array}{l}\text { originated in } \\
\text { Other socialist } \\
\text { countries }\end{array}$ & $\begin{array}{l}\text { the rest of } \\
\text { the world }\end{array}$ \\
\hline & \multicolumn{4}{|c|}{ (pieces) } \\
\hline $\begin{array}{l}\text { Small computers } \\
\text { Small/medium } \\
\text { Medium } \\
\text { Medium/large } \\
\text { Large mainfames }\end{array}$ & $\begin{array}{r}419 \\
28 \\
171 \\
26 \\
2\end{array}$ & $\begin{array}{r}255 \\
8 \\
4 \\
- \\
-\end{array}$ & $\begin{array}{r}26 \\
10 \\
113 \\
17 \\
-\end{array}$ & $\begin{array}{r}138 \\
10 \\
54 \\
9 \\
2\end{array}$ \\
\hline \multirow[t]{2}{*}{ Total: } & 646 & 267 & 166 & 213 \\
\hline & \multicolumn{4}{|c|}{$(\%)$} \\
\hline $\begin{array}{l}\text { Small computers } \\
\text { Small/medium } \\
\text { Medium } \\
\text { Medium/large } \\
\text { Large mainframes }\end{array}$ & $\begin{array}{l}100.0 \\
100.0 \\
100.0 \\
100.0 \\
100.0\end{array}$ & $\begin{array}{l}60.9 \\
28.6 \\
2.3 \\
- \\
-\end{array}$ & $\begin{array}{r}6.2 \\
35.7 \\
66.1 \\
65.4 \\
-\end{array}$ & $\begin{array}{r}32.9 \\
35.7 \\
31.6 \\
34.6 \\
100.0\end{array}$ \\
\hline Total: & 100.0 & 41.3 & 25.7 & 33.0 \\
\hline
\end{tabular}

comprise $26.5 \%$ of the whole computer population--database services could basically provide an SDI regime, also because of the software used. The remaining, approximately $70 \%$, of the computer population is practically of no use for providing public database services. Table 9 shows that in 1979 the majority of the medium and large mainframes were Ryad I machines (actually $R-20, R-22$ and $R-40 s$ ), which is accordingly expressed in Table 1. The average number of peripherals belonging to these com- 
Table 9. Number of computers in Hungary (data end of 1979) according to their performance category and compatibility with the Ryad series. (Source: [3] 1981, Szamitastechnikai Statisztikai Evkonyv 1980).

\begin{tabular}{lcccc}
\hline $\begin{array}{l}\text { Computer } \\
\text { performance } \\
\text { category }\end{array}$ & Total: & $\begin{array}{l}\text { Out of this } \\
\text { Ryad } \\
\text { (ES) }\end{array}$ & $\begin{array}{l}\text { Ryad } \\
\text { compatible }\end{array}$ & $\begin{array}{l}\text { incompatible } \\
\text { with Ryad }\end{array}$ \\
\hline & & & (pieces) & \\
\hline Small computers & 419 & 82 & 4 & 333 \\
Small/medium & 28 & - & - & 28 \\
Medium & 171 & 100 & 27 & 44 \\
Medium/large & 26 & 19 & 5 & 2 \\
Large mainfames & 2 & - & 1 & 1 \\
Total: & 646 & 201 & 37 & 408 \\
\hline & & & $(\%)$ & 79.4 \\
\hline Small computers & 100.0 & 19.6 & 1.0 & 25.7 \\
Small/medium & 100.0 & - & - & 7.7 \\
Medium & 100.0 & 58.5 & 15.8 & 50.0 \\
Medium/large & 100.0 & 73.1 & 19.2 & 63.2 \\
Large mainframes & 100.0 & - & 50.0 & \\
Total: & 100.0 & 31.1 & 5.7 & \\
\hline
\end{tabular}

puter installations in Hungary is shown in Table 10, which proves that the average computer installation in Hungary around that time was basically a batch oriented system (the average number of terminals being extremely low!), with a moderate number of dise drives per installation. By looking at these figures one can almost guess the type of public database services they can offer. Table 11 underlines what is said above that out of the 25 registered information retrieval system installations of Hun- 
gary [3] most were running under Ryad or IBM batch systems.

Table 10. Average number of peripherals belonging to computer intstallation in Hungary (data: end of 1979). (Source: [3] 1981, Szamitastechnikai Evkonyv 1980).

(pieces)

\begin{tabular}{|c|c|c|c|c|c|c|}
\hline Device & Total & Small & $\begin{array}{l}\text { Small/ } \\
\text { medium }\end{array}$ & $\begin{array}{l}\text { Medium } \\
\text { mainfrar }\end{array}$ & $\begin{array}{l}\text { Medium/ } \\
\text { large } \\
\text { nes }\end{array}$ & Large \\
\hline Number of mainframes & 646 & 419 & 28 & 171 & 26 & 2 \\
\hline Visual display unit & 1.0 & 1.4 & 0.0 & 0.3 & 1.6 & 1.5 \\
\hline Lineprinter & 1.1 & 0.9 & 0.9 & 1.7 & 2.2 & 3.0 \\
\hline Console & 0.9 & 0.7 & 0.9 & 1.1 & 1.5 & 1.5 \\
\hline Papertape reader & 0.8 & 0.8 & 1.4 & 0.9 & 1.0 & - \\
\hline Papertape puncher & 0.6 & 0.7 & 0.8 & 0.5 & 0.5 & - \\
\hline Card reader & 0.6 & 0.3 & 0.5 & 1.4 & 1.8 & 1.0 \\
\hline Card puncher & 0.1 & 0.0 & 0.0 & 0.3 & 0.3 & - \\
\hline Card reader/puncher & 0.1 & 0.0 & 0.2 & 0.1 & - & - \\
\hline Magnetic tape drive & 2.2 & 0.9 & 1.1 & 4.7 & 6.8 & 7.0 \\
\hline Magnetic casette device & 0.2 & 0.3 & 0.3 & 0.0 & - & - \\
\hline Magnetic disc drive & 2.9 & 1.1 & 1.4 & 6.5 & 8.8 & 11.5 \\
\hline Disc/tape controller & 0.3 & 0.0 & - & 0.9 & 1.7 & - \\
\hline Other peripherals & 1.8 & 2.2 & 1.5 & 1.0 & 1.3 & 2.0 \\
\hline Total & 12.7 & 9.3 & 9.0 & 19.3 & 27.5 & 27.5 \\
\hline
\end{tabular}

The hardware and system software situation is, however, just about to change. With the introduction of the Ryad II series, which started around the end of the seventies, a new computer generation is gradually taking over the place of the old database service computer generation, the one which is shown in the above statistics. 
Table 11. "Registered" computer application program packages according to application categories and type of computers (in 1979). (Source: [8] OSAK*, Számitástechnikai Statisztikai Évkönyv 1980)

\begin{tabular}{|c|c|c|c|c|c|c|}
\hline \multirow{2}{*}{ Application packages } & \multicolumn{2}{|c|}{ ES-IBM } & \multirow{2}{*}{$R-10$} & \multirow{2}{*}{$\begin{array}{l}\text { Other } \\
\text { CMEA } \\
\text { systems }\end{array}$} & \multirow{2}{*}{$\begin{array}{l}\text { Other } \\
\text { non-CMEA } \\
\text { systems }\end{array}$} & \multirow{2}{*}{ Total } \\
\hline & DOS & OS & & & & \\
\hline "Classical" data processing & 198 & 3 & 4 & 5 & 177 & 387 \\
\hline Production control & 80 & 2 & 8 & 1 & 53 & 144 \\
\hline Financial & 61 & 2 & 15 & 1 & 46 & 125 \\
\hline Statistical & 25 & 4 & 7 & - & 17 & 53 \\
\hline Operation research & 19 & 2 & 3 & 2 & 4 & 30 \\
\hline Mathematical & 30 & 5 & $B$ & 3 & 16 & 62 \\
\hline Numerical control & - & 1 & - & - & - & 1 \\
\hline Process control & 2 & - & 1 & - & $=$ & 3 \\
\hline Database management systems & 22 & - & 2 & - & 8 & 32 \\
\hline Information retrieval systems & 16 & 1 & 2 & - & 6 & 25 \\
\hline Scientific-technological & 95 & 24 & 18 & 161 & 89 & 387 \\
\hline System programs, utilities & 11 & 2 & 2 & - & 5 & 20 \\
\hline Software development tools & 21 & 10 & 8 & - & 5 & 44 \\
\hline Others & 61 & 4 & 5 & 2 & 26 & 98 \\
\hline Total: & 641 & 60 & 83 & 175 & 452 & 1411 \\
\hline
\end{tabular}

* Országos Software Archivum és Követőszolgálat (National Software Archive and Register Service).

Already in 1979 two R-35s were delivered and installed in Hungary [3] and according to Table 1 , one R-55 is taking over the servicing of the "mammoth" AOBIPD database. The Hungarian National Technical Library and Documentation Center (OMKDK), which services five major database services, put a new R-35 configuration into service, in 1981, which gradu- 
ally took over the task of an old, less powerful R-20 [5]. The Ryad II series model R-35 with a configuration of 1 MByte CPU capacity, 640 MByte dise capacity and 16 terminals for remote working, delivered at the end of 1980 has already allowed for the upgrading (Figure 1) of OMKDKs domestic services considerably.

First OMKDK plan to provide offline services and then introduce online services. They foresee keeping the $\mathrm{R}$ - 20 with the present DOS based batch services until 1984.

OMKDK is planning to use database handling systems available in Hungary and not to develop any systems themselves. They believe that the two most suitable packages for their purposes are DIALOG-KAMA from the Soviet Union and CDS/ISIS from the United Nations (ILO, UNESCO).

In general, the medium and larger models of the new Ryad II series are better suited to providing public database services (Table 12, compiled by $\operatorname{CDC}[6,7]$ on the basis of information and sales brochures and personal discussions). A particularly interesting new version of the R-55 was presented along these lines by the GDR manufacturers Robotron at the Leipzig Fair in March 1982 [B]. A double processor EC-1055/EC-1055M configuration (Figure 2) linked together with direct channels KKA-ES 4065 is sufficiently large enough to host major database services. The double processor capability is particularly suitable for secure online database services

As pointed out earlier, the availability of sufficiently large secondary storage capacity on magnetic discs or similar devices are of utmost importance for providing online database services. For a long period the 


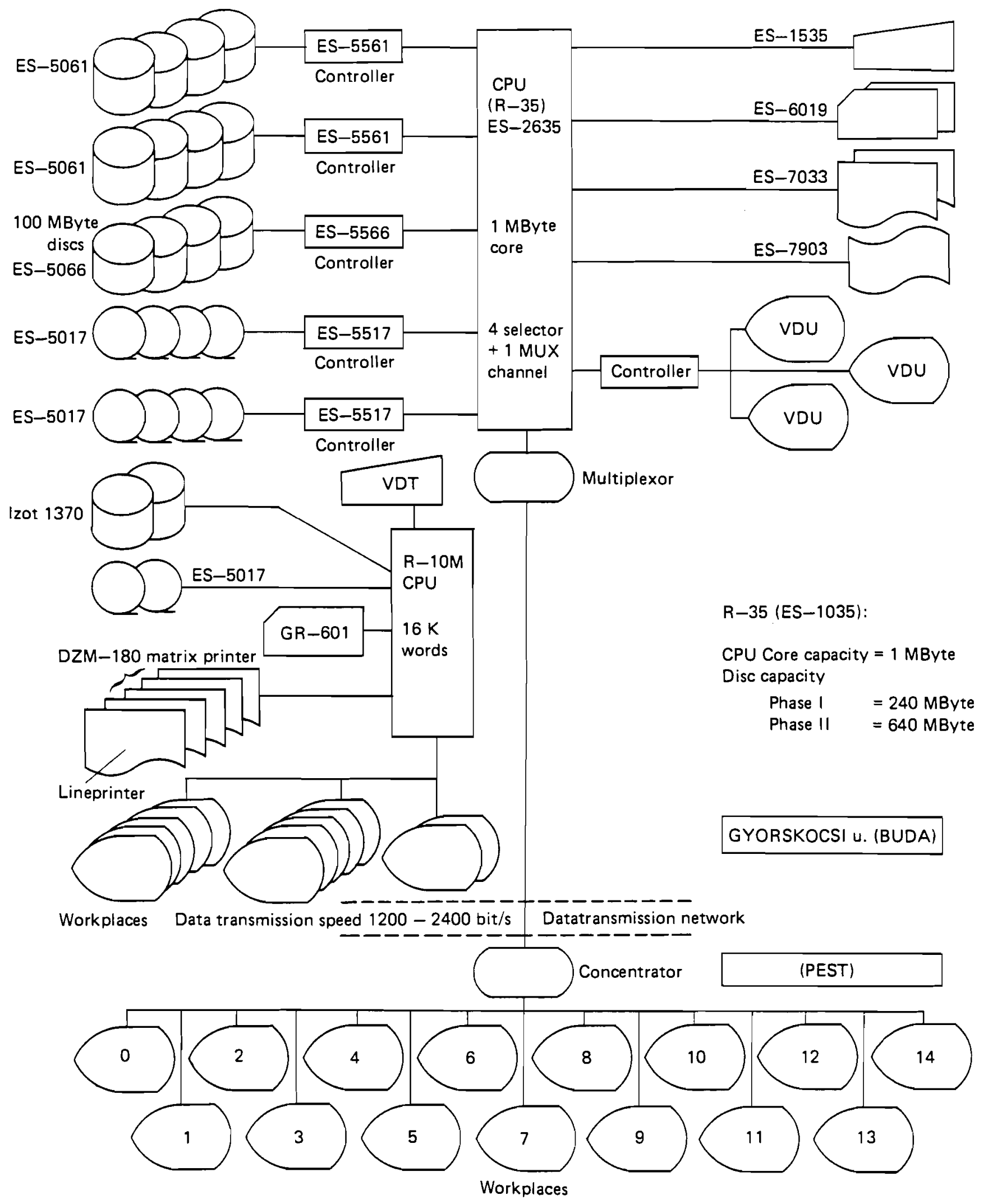

Figure 1. Example of a Hungarian data center configuration (ONKDK) based on an R-35 computer, supported by an R-10N processing system [5]. 
Table 12a. RYAD I Central Processor Profile. [6]

\begin{tabular}{|c|c|c|c|c|c|c|c|}
\hline \multirow{2}{*}{$\begin{array}{l}\text { Background } \\
\text { Country of origin }\end{array}$} & \multicolumn{7}{|c|}{$\begin{array}{c}\text { Model } \\
\text { ES-1020 ES-1022ES-1030ES-1032 }\end{array}$} \\
\hline & \multicolumn{3}{|c|}{ Bulgaria Bulgaria Poland } & Poland & \multirow[t]{2}{*}{ USSR } & \multirow{2}{*}{$\frac{\text { GDR }}{197 ?}$} & USSR \\
\hline Prototype date & 1971 & & 1972 & 1974 & & & 1973 \\
\hline First delivery & 1972 & $1977(?)$ & 1973 & 1975 & & 1973 & \\
\hline $\begin{array}{l}\text { Annual production } \\
\text { rate }\end{array}$ & & & & 25 & & 50 & \\
\hline Installations & & & & 100 & & 300 & \\
\hline \multicolumn{8}{|l|}{ Characteristics } \\
\hline \multicolumn{8}{|l|}{ Processor speeds* } \\
\hline \multicolumn{8}{|l|}{ Fixed point ( $32 \mathrm{bit}$ ) } \\
\hline Add/subtract & 33.4 & 6.5 & 13.3 & 2.6 & 2.0 & 1.9 & 1.9 \\
\hline Multiply & 349.0 & 57.6 & 14.1 & 9.3 & 11.0 & 7.6 & 2.2 \\
\hline Divide & 398.0 & 65.0 & 112.0 & 17.7 & 15.2 & 11.4 & 8.5 \\
\hline \multicolumn{8}{|c|}{ Floating point ( 32 bit) } \\
\hline Add/subtract & 70.8 & 15.5 & 16.3 & 5.0 & 5.0 & 3.7 & 1.9 \\
\hline Multiply & 413.0 & 36.3 & 37.5 & 13.2 & 9.0 & 6.4 & 2.4 \\
\hline Divide & 399.0 & 52.4 & 58.7 & 14.5 & 13.2 & 8.4 & 5.9 \\
\hline \multicolumn{8}{|c|}{ Floating point (64 bit) } \\
\hline Add/subtract & 94,3 & 17.8 & 25.9 & 6.3 & 5.9 & 4.2 & 1.8 \\
\hline Multiply & 1200.0 & 54.7 & 140.0 & 28.7 & 19.0 & 6.4 & 2.4 \\
\hline Divide & 2150.0 & 128.0 & 218.0 & 48.2 & 29.3 & 16.1 & 10.8 \\
\hline Cache memory* & No & No & No & No & No & No & No \\
\hline Average speed (MIPS) & 0.025 & 0.080 & 0.10 & 0.29 & 0.20 & 0.38 & 0.5 \\
\hline Processing data rate & 0.83 & 5.45 & 3.30 & 14.4 & 18.4 & 21.3 & 25.7 \\
\hline \multicolumn{8}{|l|}{ Main memory* } \\
\hline Type & CORE & CORE & CORE & CORE & CORE & CORE & CORE \\
\hline Max capacity & 250 & 500 & 500 & 1,000 & 500 & 1,000 & 1,000 \\
\hline Cycle time & 2.0 & 2.0 & 1.25 & 1.3 & 1.25 & 1.35 & 1,25 \\
\hline Access width (bytes) & 1 & 4 & 4 & 4 & 4 & 8 & $B$ \\
\hline \multicolumn{8}{|l|}{ Channels* } \\
\hline \multicolumn{8}{|l|}{ Selector } \\
\hline Number & 2 & 2 & 3 & 3 & 3 & 6 & 6 \\
\hline Maximum rate /ch. & 300.0 & 500.0 & 800.0 & 1030.0 & 800.0 & 1300.0 & 1250.0 \\
\hline \multicolumn{8}{|l|}{ Multiplexor } \\
\hline Number & 1 & 1 & 1 & 1 & 1 & 1 & 1 \\
\hline Burst rate & 140.0 & 300.0 & 300.0 & 240.0 & 350.0 & 720.0 & 180.0 \\
\hline
\end{tabular}

* Times are given in microseconds capacities in kilobytes (KB) and transfer rates in megabits/second instruction times assume data in memory. 
Table 12b. RYAD II Profile.

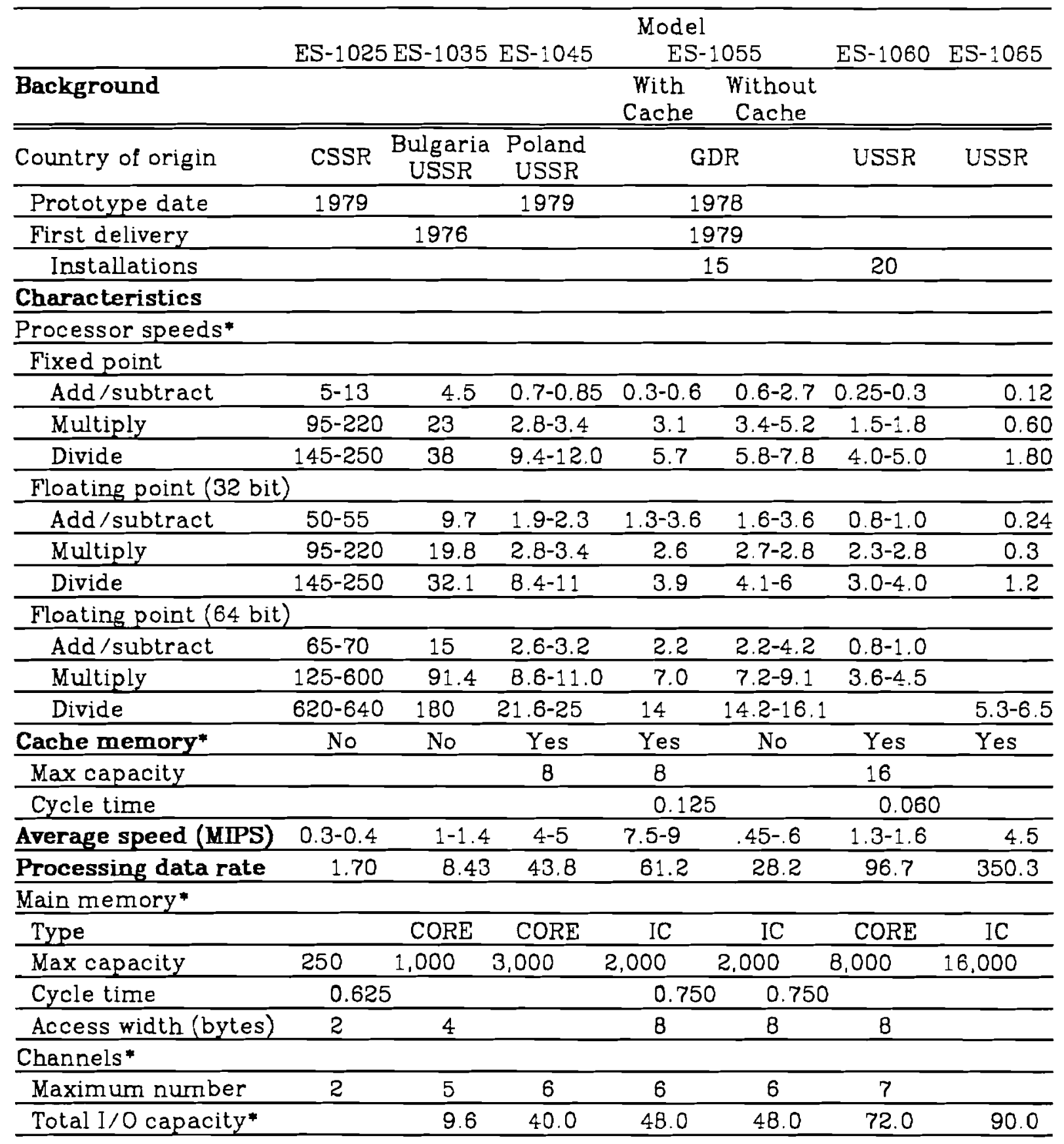

* Times are given in microseconds capacities in kilobytes (KB) and transfer rates in megabits/second instruction times assume data in memory. 


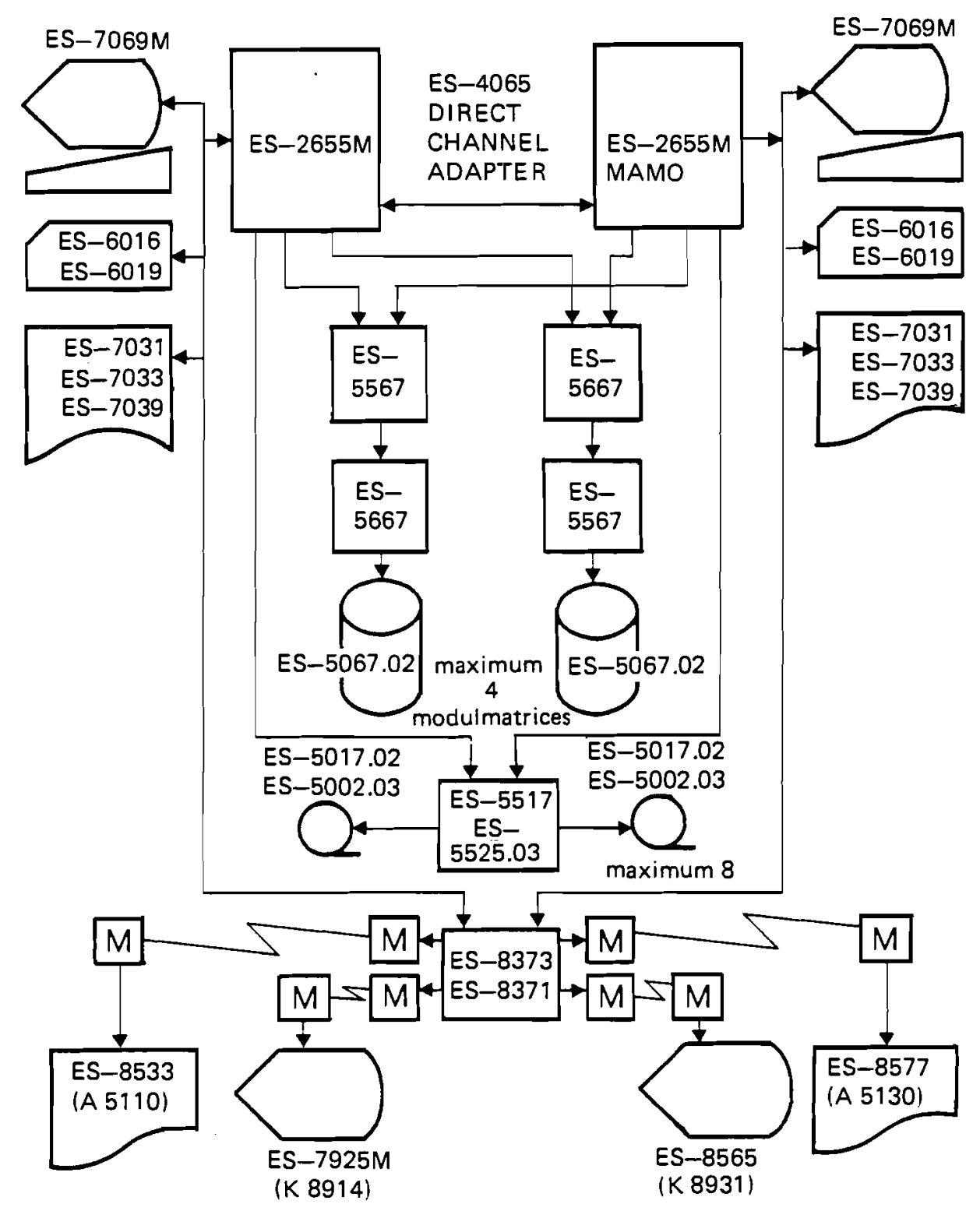

Figure 2. Double-processor EC-1055/EC-1055 M configuration [B] 
disc storage capacity of Ryad disc drives actually presented a bottleneck for providing larger online database services.

Early Ryad models equipped with ES-5052 and ES-5056 disc drives with a storage capacity of only 7.25 MByte per unit were not really suitable for such types of applications. Nonetheless these were the only ones that could be delivered to the models $\mathrm{R}-20$ and $\mathrm{R}-40$ until the second half of the seventies when the Bulgarian made ES-5061 unit with 29 MByte storage capacity appeared on the market. Actually, when the sampling of Hungarian databases was taken in early 1981 these three types of disc units were the ones tend to be most commonly used in Hungarian Ryad installations. Since all Ryad disc controllers can accommodate up to 8 disc drives, an early model of an R-20 maximally 58 MByte disc storage could be linked to--let us say-- a ES-5551 or ES-5552 controller. However, this is not really enough for online services. An ES-5566 disc controller, on the other hand, could accommodate 232 MByte secondary storage capacity, which easily allows the operation of medium size databases online. Since up to 5 such controllers can be linked (reserving the 6th channels for tapes), let us say an R-40 to as a maximum 1,160 MByte disc storage capacity could be accumulated, which is sufficient for online database services.

Obviously, with the new 100 MByte Ryad disc drives that became available around the end of the seventies, all secondary storage problems for database services can in principle be solved. Up to 96 ES-5060 disc drives with 9.28 GByte capacity could be connected to an R-60 in its maximum configuration (Figure 3 ). This capacity is more than enough for providing online data services. The ES-5566 disc controller and the ES- 
5066 disc unit models are nowadays standard elements of Ryad II computer configurations, and this equipment has been in production in the USSR for the last couple of years. The Bulgarian equivalent of the 100 MByte disc devices have become also available, for example, the R-55 model shown at the Leipzig Fair was equipped with ES-5567 controllers and ES-5067-02 drives. 200 MByte disc drives (ES-5067), basically double density versions of the Bulgarian ES-5067-02 drive, have also been announced and were already on display at the CMEA computer exhibition held in Moscow in June and July $1979[6,7]$ (Table 3).

All in all, the disc storage capacity problem of Ryad models seems to be solved, and these days the large Ryad configurations under delivery are suitable for providing online database services from the point of view of computer hardware.

\subsection{Information Retrieval Software Used}

On the basis of [4]. Table 4 shows the list of information retrieval software packages used in Hungary in 1980 for public database services. The basic trends are the following: In most cases--for the largest databases--the program package BINAR developed by the Central Physical Research Institute of the Hungarian Academy of Sciences (KFKI) was used. BINAR in its present version allows the sequential processing of data files, mainly used for SDI services. A more detailed description of the BINAR program is found in [9]. According to the authors of [9] the present version of the system can be run on Ryad and IBM machines both in DOS and OS environments, and because it is so flexible it can be adapted to databases with different record formats. The system can also 


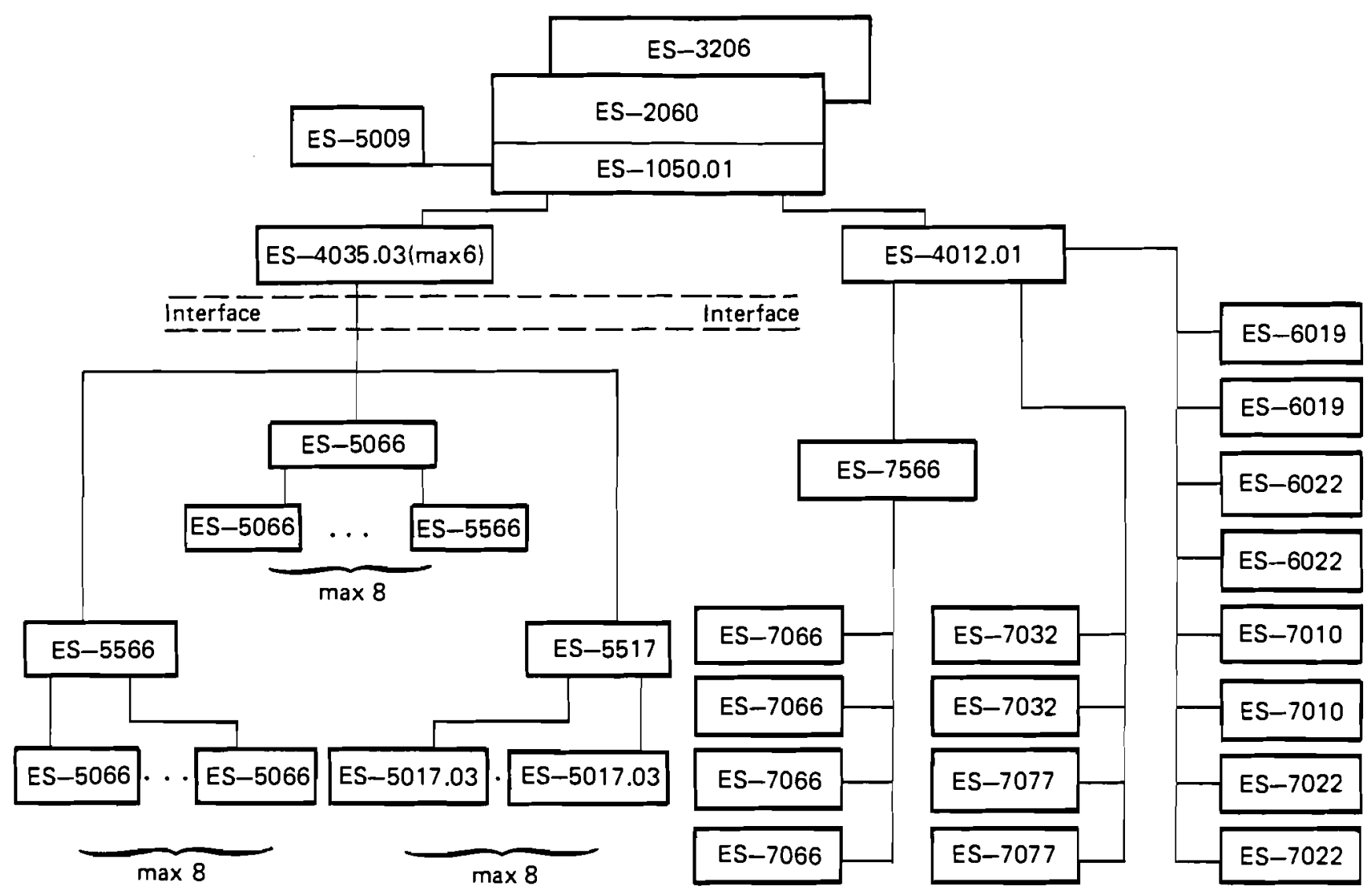

The ES-1060 configuration can be based on the following devices:

$\begin{array}{ll}\text { Processor } & \text { ES-2060 } \\ \text { Main storage } & \text { ES-3206 } \\ \text { Multiplexor channel } & \text { ES-4012.01 } \\ \text { Selector channel rack } & \text { ES-4035.03 } \\ \text { Control panel } & \text { ES-1501.01 } \\ \text { Console magnetic tape unit } & \text { ES-5009 } \\ \text { Power supply } & \text { ES-0824 and ES-0825 } \\ \text { Power switching device } & \text { ES-0853.01 } \\ \text { Interchangeable magnetic } & \\ \text { Disc storage } & \text { ES-5066 } \\ \text { Disc storage control } & \text { ES-5566 } \\ \text { Magnetic tape storage } & \text { ES-5017.03 (ES-5025) } \\ \text { Magnetic tape control } & \text { ES-5517 (ES-5525) }\end{array}$

\section{Processor}

Selector chan

Control pane

Power suppli

Disc storage

Magnetic tape storage

\author{
ES-4035.03 \\ ES-1501.01 \\ ES-0824 and ES-0825 \\ S-0853.01 \\ ES-5566 \\ ES-5517 (ES-5525)
}

Card reader

Paper tape reader

Card punch

Paper tape punch

Alphanumeric printer

Typewriter with control 4 display group control (ES-7566) with display terminals (ES-7066)

Card read punch

Card verifier

Paper tape data recorder
ES-6019 (ES-6015)

ES-6022

ES-7010

ES-7022

ES-7032

(ES-7033, ES-7037)

ES-7077

ES-7906

ES-9011.01

ES-9013.01

ES-9024

Figure 3. ES-1060 Specifications

Source: ELORG Brochure - USSR 
Table 13. RYAD Disc Products [6]

\begin{tabular}{|c|c|c|c|c|c|c|}
\hline \multirow{3}{*}{$\begin{array}{l}\text { Country of origin } \\
\text { Unit capacity (MB) } \\
\text { Access time (MS) }\end{array}$} & \multirow{2}{*}{$\begin{array}{c}\text { ES-5052 } \\
\text { Bulgaria }\end{array}$} & \multicolumn{2}{|c|}{ ES-5056 ES-506 } & $\begin{array}{l}\text { Model } \\
\text { ES-5066 }\end{array}$ & \multicolumn{2}{|c|}{ ES-5067-02 ES-5067 } \\
\hline & & $\begin{array}{r}\text { USSR } \\
7.25\end{array}$ & $\begin{array}{c}\text { Bulgaria } \\
29\end{array}$ & $\begin{array}{l}\text { USSR } \\
100\end{array}$ & $\begin{array}{l}\text { Bulgaria } \\
100\end{array}$ & $\begin{array}{c}\text { Bulgaria } \\
200\end{array}$ \\
\hline & & & & & & \\
\hline Minimum & 20 & 25 & 20 & & & \\
\hline Maximum & 95 & 150 & 80 & & & \\
\hline Average & 45 & 66.7 & 40 & & & \\
\hline Transfer rate (KBS) & 156 & 156 & 312 & 806 & 806 & 806 \\
\hline Disc controllers & $\begin{array}{l}\text { ES-5551 } \\
\text { ES-5552 } \\
\text { ES-5555 } \\
\text { ES-5558 }\end{array}$ & ES-555E & $8 \mathrm{ES}-5561$ & ES-5566 & ES-6667 & \\
\hline
\end{tabular}

be extended to handle [10] so-called inverted files, which would allow for an appropriate online version of BINAR to be developed with relative ease.

Other SDI systems are often provided by the database supplier himself. This is the case, for example, with DERWENT Ltd. For other database services, the information retrieval software of the computer suppliers was used. For example, the online database services run on Siemens computers used the BS 2000 version of the GOLEM system, which was originally developed for the 1972 Olympic Games in Munich. 
Some of the database services run on software developed by the service provider himself. Some of them even handle very large databases, for example, the program package PA developed by KG-INFORMATIK.

For its online database services SZÁMOK uses SZAMOK-ISIS, a system originally developed by the International Labour Organization (ILO) in Geneva, but developed further by SZÁMOK to a version allowing online retrieval. This system is called ISIS-BABILON and is run on SZAMOK'S IBM $370 / 145$ computer. In an online regime ISIS-BABILON allows many users to access the system simultaneously--unlike the ILO online version of the system. ISIS-BABILON also allows the use of a greater variety of terminaI types. A more detailed description of the ISIS-BABILON system can be found in [10]. There are also other database retrieval systems in use in Hungary, which are suitable for database services, such as the DIALOGKAMA and STAIRS mentioned before. They could be used in providing public services.

All in all it appears that the information retrieval sof tware for future database computer systems will not become a bottleneck in the next couple of years. They may not be the best possible systems available worldwide, but they will nonetheless allow for a respectable information retrieval system.

\subsection{Telecommunication Needs of Database Services}

As mentioned above the majority of database services in Hungary, when the last statistics were taken, were provided in an offline regime by medium size computers. The majority of these computers were not adequate for connection to telecommunication networks, however, and the 
offline regime and the relatively small size of the country did not really necessitate links to telecommunication networks. The data communication service options offered in different forms by the Hungarian PTT, in the early seventies were only of marginal interest for these systems. The few Hungarian online data services were accessed by remote users through telecommunication channels, but only in a moderate way. One of the reasons for this was that some Western European and North American computer installations only allowed access from remote users on dedic ated, non-switched lines.

This obviously caused major costs for the users and some, who would certainly have been interested in dial-up connections through the public switched telephone network, were totally discouraged from using the system at all.

The low number of online connections is, however, changing. The above mentioned models and systems of the Ryad II series are much more time sharing and data communication oriented. Thus, not only the size of the CPUs and the amount of online disc storage capacity is increasing but also the basic software systems will be better suited for remote access.

Simultaneously with this development the Hungarian PTT has also upgraded its data communication services. In 1981 the national circuit switching PTT Network NEDIX became operational--supporting terminal to computer access in a flexible way. The national PTT network is gradually being connected to other national networks as well, the first link being established with the Austrian telecommunication authorities in July 1982. It is expected that links with other national networks will follow soon. 
Through this arrangement, Hungarian terminals are able to reach Hungarian database hosts linked to the network, and hosts abroad.

In a similar way, Hungarian hosts are accessible from terminals in foreign countries, the first opportunity for Hungarian database hosts to supply a database service to customers abroad. Looking at the present list of database services, however, there are very few that could be of potential use to a foreign customer at present. Access to pure Hungarian keywords or Hungarian abstracts, such as SZAMOK-ISIS, is of limited use to them, since major databases of international interest such as CA SEARCH, INSPEC, etc., are also available in many other countries and from other online database hosts, such as LOCKHEED, ESA or SDC. A real interest and a real potential for database services from Hungary would be if major CMEA databases were serviced from Hungarian hosts or if very specialized database were offered. One of the unique and specialized databases available now is the ${ }^{13} \mathrm{C}$-NMR database. Such a database can be developed without major hardware resources, since it is relatively small in size. One experiment along these lines is known to us [11]: The Hungarian Academy of Sciences is installing an online bibliographical database under STAIRS on "Mass Communication Research"--compiled in English and Russian by the Central European Mass Communication Research Documentation Center (CECOM) in Krakow, Poland on their IBM 3031 computer. This database, with its few thousand information records, is small, but is not available on any other online host in the world.

Because of the high investment costs the decision of setting up and installing new online databases has obviously to be preceded by detailed cost and benefit analysis and market research. 


\section{B. Online Access to Databases Abroad from Hungary}

Experimental online access to foreign public database services from Hungary goes back according to [4] as early as 1977. Between 1977 and 1979 several online experiments were carried out with connections being established to SDC and Lockheed in California, the IAEA in Vienna, ESAESRIN in Frascati--to mention only a few.

The first experimental service to foreign public databases was promoted in May 1979, when a leased data communication line was installed between the Institute for Automation and Computerization of the Hungarian Academy of Sciences (SZTAKI) in Budapest and the International Institute for Applied Systems Analysis (IIASA) in Laxenburg. Using a TPA70, a Hungarian made minicomputer-switching node was developed and brought into operation. The regular experimental service of the IIASA node started in July 1980 [12]. The main purpose of the IIASA node, and in particular the Budapest link, was its utilization for the joint research work between IIASA and Hungarian institutions. However, and practically as a side effect, it has also been used for experimental access to other data centers, such as the IAEA in Vienna for the databases INIS and AGRIS, and ESA in Frascati, etc. [13]. The IIASA-SZTAKI link was further developed in 1981 to a circuit switching gateway network with another TPA-70 node in Budapest [11]. Through this gateway network it became possible to access the CECOM experimental database on the SZTAKI computer in Budapest for the first time. A new packet switching system was implemented in early 1982, which allowed increased throughput of the system 
Until November 1981 several Hungarian institutions--such as ONKDK, the Library of the Hungarian Academy of Sciences, the Library of the Chemical University in Veszprem and the Institutes of the Hungarian Academy of Sciences--made experimental connections through the IIASASZTAKI link to foreign public database services [14].

In early 1982 the Hungarian PTT and Radio Austria GmbH in Vienna started experiments to interlink the NEDIX computer network to the network node of Radio Austria. By spring 1982 the two systems were successfully interconnected by 3 multiplexed 1200 baud, X.20 channels. The official service by Radio Austria to Hungarian hosts accessible over the Radio Austria node started in July 1982.

As soon as the above PTT service became operational all connections to foreign public data services from and to Hungary have in principle to use the data network services PTT. Obviously connections through the public switched telephone or telex network are also still possible.

Data connections to CMEA countries became operational almost at the same time as the IIASA-SZTAKI TPA-70 gateway started to take up its regular services.

According to [4] and [15] the National Technical Library and Documentation Center (OMKDK) provides online service in Hungary for access over public switched telephone networks to the bibliographic databases of the International Information Center on Science and Technology (MCNTI) in Moscow. The experiments with the MCNTI system actually started in 1979 before the CMEA computer exhibition held in Moscow [16], where it was presented. The system used there, and a similar one that is 
at present in operation at ONKDK (Figure 4) is built on an ES-1040 (R-40) database center at MCNTI under the system OS-ES 4.1. For telecommunication the Hungarian made Orion hardware and the telecommunication monitor software KAVA (similar to IBM CICS) is used. The three databases serviced by MCNTI run under the information retrieval system KAMADIALOG, which is similar in its characteristics to ISIS or STAIRS. The databases serviced by MCNTI include: INIS (from the IAEA in Vienna), the Soviet VINITI database and the CNEA database IICST-SIISRB (the last two databases are also included in Table 2 because installation of them on Hungarian hosts is planned as well).

For information concerning the costs of using foreign database see chapter 2.3 where this has been discussed in detail.

All in all, it can be said that online access to databases abroad from and to Hungary is increasing. This rapid development necessitated the recent establishment of Hungarian Association for Online Computer Services (SZIT - Szamitogepes Informacios Tarsasag) by leading Hungarian information and documentation service institutions such as (SZKI, SZASTKI, SZAMALK, OMIK, KKI, MTA Library, etc.) with the goal of coordination major activities (such as training, contacts to online vendors and database suppliers, compensation business, etc.) in this field. 


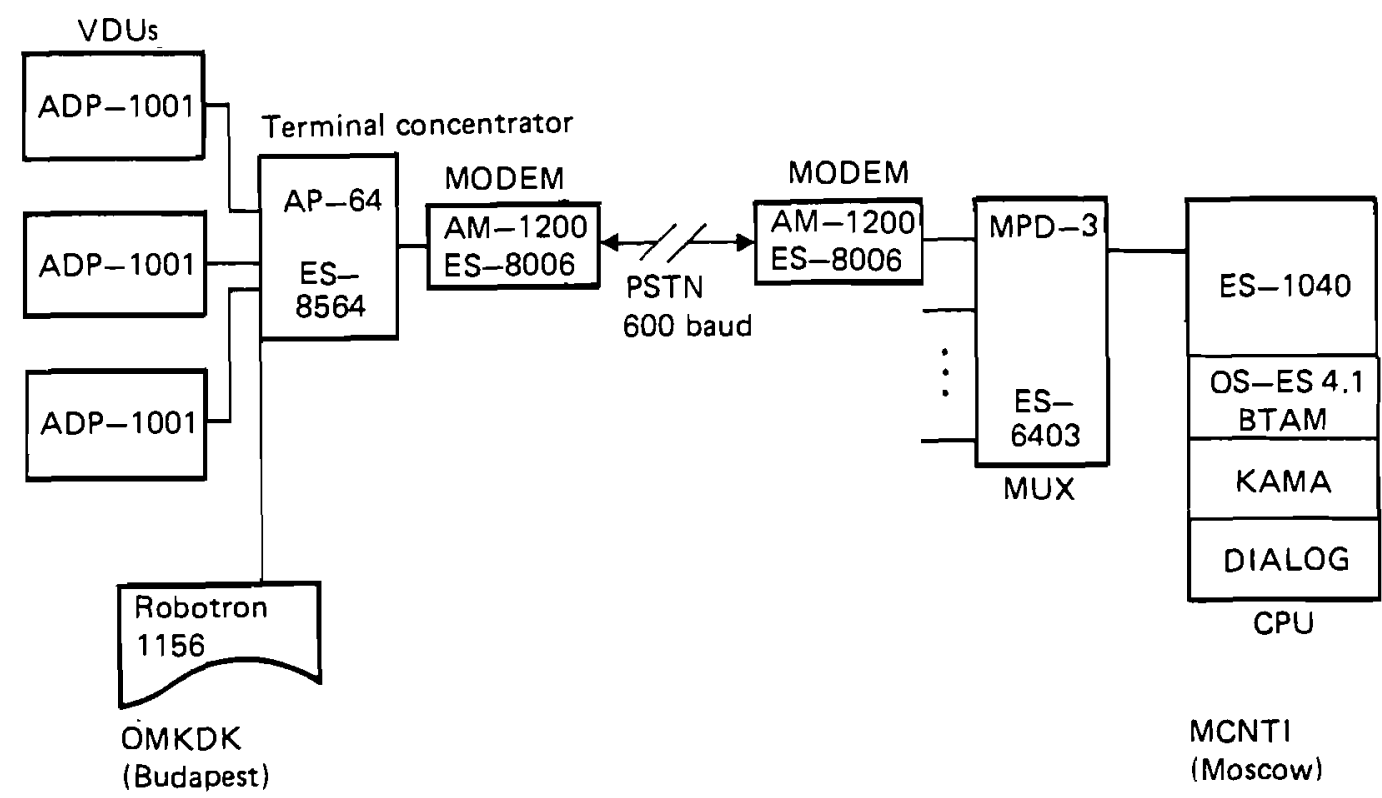

Figure 4. Hardware and system configuration for access from OMKDK in Budapest to the databases of MCNTI in Moscow [15].

\section{CONCLUSIONS}

(1) Public database services with bibliographic references and factual data have existed in Hungary for quite a long time, originating in the early seventies. In addition, the Hungarian public library and documentation services go back in history for about 150 years generating 
experience and well established traditions. This meant that there was fertile ground ready to accept the new technology, which in essence was nothing more than another powerful and useful tool to perform their functions. Accordingly not only the providers of such services had relatively long experience with databases, but also the users of them, such as companies in the chemical and pharmaceutical industry or in the scientific community.

(2) The nature of public database services in Hungary is just about to change. Up until now offline database services--and in particular SDI have dominant, but with the introduction and penetration of the more powerful Ryad II series and the introduction of new national data services the trend towards increasing online services should not be overlooked. It can be expected that online services will be dominant in Hungary by about 1985.

(3) The necessary training, and provision and use of online services are some of the tasks that need to be solved. However, if one is aware what databases are all about, the change from offline to online is actually not a basic one. We do not expect that retraining and education will be a major barrier for the penetration of online services in Hungary, for the following reasons:

Because of the high degree of interaction between user and system in online services increased comfort of access allows users to educate themselves easily. Second, Hungarian educational institutions in the field of computing, such as SZAMOK, are considering launching online education courses [17]. The fact that SZAMOK runs one of the major Hungarian online database services in its own library will also 
be of help in educating the old and new generation of information professionals and users.

(4) In Hungary there are at present 25 databases in operation and 13 under immediate preparation. Although this is not small for a country like Hungary, the number could be much larger.

The high growth rate figures in terms of databases, number of service providers and number of users, suggest that the database industry in Hungary will become stronger in the next couple of years.

(5) International cooperation and transborder data flow in the field of databases will also be of utmost importance to the country. Similar to other small countries with limited financial, technical, informational and manpower resources, international cooperation in production, distribution, and the use of databases will be crucial. Signs of cooperation along these lines are already visible. There are a few examples of international cooperation known in the field of production, distribution, and use of databases--such as for INIS, AGRIS and some CMEA databases--but there is obviously plenty of room to broaden this collaboration. Hungary as a small country, is outstanding in some special disciplines, and has a good chance to produce and market smaller, specialized databäses in different disciplines. However, the ways of cooperation to the collection and dissemination of database information have to be consciously sought, found, and followed.

(6) Access to foreign database hosts will, for a small country like Hungary, always be of importance. Probably only those foreign data- 
bases that are economically justified or are of strategical importance to the country can be installed on Hungarian hosts, the rest have to be accessed on foreign hosts. Access to major, foreign "transactional" databases, such as stock market, commodity, latest patent news, etc., are also better accessed by large foreign networks. Access to databases abroad will be one of the important factors of the country's transborder data flow traffic, and all activities around it should be done in a way that promotes mutual interdependence for all participants and that has no negative effects on the balance of payment of the country. 


\section{REFERENCES}

[1] Hall, J.L., 1981. Online Bibliographic Databases: An International Directory. Second Edition, Aslib, London, UK.

[2] Cuadra, R.N. et al, 1981. Directory of Online Databasis. Cuadra Associates Inc, Santa Monica, California, USA.

[3] KSH Országos Számitástechnika-Alkalmazási Iroda, 1980. Számitástechnikai Statisztikai Évkoenyv 1980 (Statistical yearbook on Computer Techniques 1980), (ISSN 0139-3286). Central Statistical Office, Statistical Publishing House, Budapest, Hungary.

[4] Dúzs, J., et al, 1981. Hazai Szakirodalmi Számitógépes Információkeresoe Szolgáltatasok-Tájekoztató (Domestic Computerized Technical Information Retrieval Services - Review), OMKDK \& ETK, OMKDK Publication (ISBN 963592 2191, ISSN 0230-290x), Budapest, Hungary. 
[5] Szabó, I., et al, 1981. Számitógépes integrált információrendszer fejlesztési elképzelései az OMKDK-ban (Plans for an integrated computerized information system for OMKDK), Információ-Elektronika, 1981/5. Statistical Publishing House, Budapest, Hungary.

[6] Anonymous, 1980. State of the Art of Computer Technology in Eastern Europe. CDC Control Data Corporation Brochure.

[7] Schmidt, R.D., 1981. Soviets Catch-up Crusade, Datamation, March 1981.

[8] Dr. Sz. I., 1982. Robotron ujdonságok Lipcsében (Robotron news in Leipzig), Számitástechnika, Issue April 1982. Statistical Publishing House, Budapest, Hungary.

[9] József, E., et al, 1981. Számitógépes információ-feldolgozás a Koezponti Fizikai Kutató Intézet Koenyvtárában (Computerized information processing in the library of KFKI), InformácioElektronika 1981/5. Statistical Publishing House, Budapest, Hungary.

[10] Huba, Z.. 1981. Az ISIS-BABILON rendszer egy programozó szemével (The ISIS-BABILON system with the eye of a programmer), Információ-Elektronika 1981/5. Statistical Publishing House, Budapest, Hungary.

[11] Lábadi, A., I. Sebestyén, 1982. IIASA TPA-70 Gateway Network Promotes International Flows of Scientific Information. Transnational Data Report, Vol. v, No. 1, 1982. North-Holland Publishing, Netherlands. 
[12] Lábadi, A., 1982. IIASA Gateway System and Experiments in Daily Operation: Proceedings of the COMNET ' 81 Conference on Computer Networks from the Users' point of view, May 1981, Budapest. North-Holland Publishing, Netherlands.

[13] Bakonyi, P, I. Kiss, A. Petrenko, I. Sebestyén, 1982. Promotion of East-West Computer Communication in IIASA's International Environment and the Hungarian Case Study: Proceedings of COMNET '81 Conference on Computer Networks from the Users' point of view, May 1981, Budapest. North-Holland Publishing, Netherlands.

[14] Kiss, I., 1981. A Nemzetkoezi on-line szolgáltatások hazai hozzáféréséroel (About the domestic access possibilities of international online services), Számitástechnika, November, 1981. Statistical Publishing House, Budapest, Hung ary.

[15] Grotte, A., 1981. On-line adatbázis-lekérdezés Moszkva és Budapest koezoett (Online database retrieval between Moscow and Budapest), Számitástechnika, January 1981. Statistical Publishing House, Budapest, Hungary.

[16] Grotte, A., 1979. Orion terminálok Moszkvában (Orion terminals in Moscow), Számitástechnika, October 1979. Statistical Publishing House, Budapest. Hungary.

[17] Jacsó, P., 1981. Oktatás-tájékoztatás-online informácios kultura, Számitástechnika (Education - Information - Online information culture), November 1981. Statistical Publishing House, Budapest, Hungary. 
[18] Haraszthy, E., 1982. Input-eloeállitás az INIS adatbázisba (Input preparation for the INIS database). Tudományos - Nueszaki Információ Szakkoenyvtára Vol. 5. OMKDK \& ETK, ETK Press, Budapest, Hungary. 